\title{
Neuroprotection by BDNF against glutamate-induced apoptotic cell death is mediated by ERK and PI3-kinase pathways
}

\author{
RD Almeida', BJ Manadas ${ }^{1}$, CV Melo ${ }^{1}$, JR Gomes ${ }^{1}$, CS Mendes ${ }^{1}$, \\ MM Grãos ${ }^{1}$, RF Carvalho ${ }^{1}$, AP Carvalho ${ }^{1}$ and CB Duarte ${ }^{*, 1}$ \\ ${ }^{1}$ Center for Neuroscience and Cell Biology and Department of Zoology, \\ University of Coimbra, 3004-517 Coimbra, Portugal \\ * Corresponding author: CB Duarte, Center for Neuroscience and Cell Biology, \\ Department of Zoology, University of Coimbra, 3004-517 Coimbra, Portugal. \\ Tel: + 351239 480209; Fax: + 351239 480208; E-mail: cbduarte@ ci.uc.pt
}

Received 08.11.04; revised 29.3.05; accepted 06.4.05; published online 20.5.05 Edited by M Miura

\section{Abstract}

Neurotrophins protect neurons against glutamate excitotoxicity, but the signaling mechanisms have not been fully elucidated. We studied the role of the phosphatidylinositol 3-kinase (PI3-K) and Ras/mitogen-activated protein kinase (MAPK) pathways in the protection of cultured hippocampal neurons from glutamate induced apoptotic cell death, characterized by nuclear condensation and activation of caspase-3-like enzymes. Pre-incubation with the neurotrophin brain-derived neurotrophic factor (BDNF), for $24 \mathrm{~h}$, reduced glutamate-evoked apoptotic morphology and caspase-3-like activity, and transiently increased the activity of the PI3-K and of the Ras/MAPK pathways. Inhibition of the PI3-K and of the Ras/MAPK signaling pathways abrogated the protective effect of BDNF against glutamate-induced neuronal death and similar effects were observed upon inhibition of protein synthesis. Moreover, incubation of hippocampal neurons with BDNF, for $24 \mathrm{~h}$, increased Bcl-2 protein levels. The results indicate that the protective effect of BDNF in hippocampal neurons against glutamate toxicity is mediated by the PI3-K and the Ras/MAPK signaling pathways, and involves a longterm change in protein synthesis.

Cell Death and Differentiation (2005) 12, 1329-1343.

doi:10.1038/sj.cdd.4401662; published online 20 May 2005

Keywords: BDNF; apoptosis; extracellular signal-regulated kinase (ERK); phosphatidylinositol 3-kinase; glutamate; hippocampal neurons; Akt (PKB); Bcl-2

Abbreviations: BDNF, brain-derived neurotrophic factor; CREB, CAMP response-element binding protein; DTT, dithiothreitol; ERK, extracellular signal-regulated kinase; IC, ischemic core; IP, ischemic penumbra; JNK, c-Jun N-terminal kinase; MAPK, mitogen-activated protein kinase; MEK, MAPK/ERK kinase; NGF, nerve growth factor; NT-3, neurotrophin-3; PI, propidium iodide; PI3-K, phosphatidylinositol 3-kinase; PMSF, phenylmethylsulfonyl fluoride

\section{Introduction}

Neurotrophins play an important role in the development of the nervous system, by influencing cell survival, differentiation and cell death. ${ }^{1}$ Furthermore, gradients of neurotrophins are able to steer growth cones in vitro, acting as chemoattractants or chemorepellents, depending on the cyclic nucleotide levels within the neurons. ${ }^{2,3}$ In vivo brain-derived neurotrophic factor (BDNF) has been shown to rescue different types of neurons from ischemic, traumatic and toxic brain injury. ${ }^{4-10}$ Blocking endogenous BDNF activity leads to aggravated death of a subpopulation of hippocampal neurons after global forebrain ischemia. ${ }^{11}$ The neuroprotective role of endogenous BDNF is further supported by the observed correlation between BDNF protein levels and resistance to ischemic damage in the various hippocampal subregions. ${ }^{12}$ Furthermore, intravenous administration of BDNF 30 min after middle cerebral artery occlusion reduced infarct size in the cerebral cortex and counter-regulated $\mathrm{Bcl}-2$ and Bax expression. ${ }^{8}$ Intraventricular injection of BDNF also increased survival of rat hippocampal CA1 pyramidal neurons following transient forebrain ischemia. ${ }^{4}$ In addition to the long-term effects, neurotrophins also exhibit acute effects on neurotransmitter release, synaptic strength and connectivity. ${ }^{13,14}$

The cellular actions of neurotrophins are mediated through the activation of the Trk family of receptors, TrkA-C, and the p75 neurotrophin receptor. The latter receptor binds to all neurotrophins with a similar affinity, whereas the TrkA, TrkB and TrkC receptors are activated preferentially by nerve growth factor (NGF), BDNF and neurotrophin-3 (NT-3), respectively. ${ }^{14}$ Once activated, the Trk receptors autophosphorylate specific tyrosine residues, which serve as interaction sites for proteins endowed with $\mathrm{PTB} / \mathrm{SH} 2$ domains. The consequences of Trk receptor activation include the activation of Ras, mediated by the adapter proteins Shc/Grb2/SOS, leading to the activation of extracellular signal-regulated kinases (ERK), members of the mitogen-activated protein kinase (MAPK) family, and of phospholipase $\mathrm{C}-\gamma$ and phosphatidylinositol 3-kinase (PI3-K). Phospholipase C- $\gamma$ generates diacylglycerol and inositol 1,4,5-trisphosphate, and $\mathrm{PI} 3-\mathrm{K}$ forms $3^{\prime}$-phosphorylated phosphoinositides, which allow the activation of $\mathrm{pH}$-containing proteins, including Akt/PKB. ${ }^{1}$ Activation of Akt has acute effects on cell survival, due to phosphorylation of Bad, which in the phosphorylated form is sequestered in the cytosol by 14-3-3, precluding its proapoptotic effects on the mitochondria. ${ }^{15}$ Furthermore, active ERKs and Akt are translocated to the nucleus where they can phosphorylate certain transcription factors, thereby regulating the expression of specific genes that contribute to cell survival. ${ }^{1,16}$

Neurotrophins were shown to protect cultured hippocampal neurons from glutamate-evoked cell death, by upregulating the antioxidant defense system. ${ }^{17}$ During overstimulation of 
glutamate receptors, the mitochondria become de-energized and produce reactive oxygen species due to the accumulation of large amounts of $\mathrm{Ca}^{2+} .{ }^{18-21}$ It has been proposed that the ability of mitochondria to recover their energetics after a glutamate insult determines the mode of cell death, by apoptosis or by necrosis. ${ }^{18}$ Neuronal death by apoptosis is characterized by the release of cytochrome $c$, which allows the activation of caspase- 9 . This caspase acts upstream of caspase-3, the major executioner caspase in neurons. ${ }^{22-25}$ Although neurotrophins protect hippocampal neurons in vivo and in vitro, the signaling mechanisms responsible for this protection are still not fully understood. In the present work, we determined the role of the PI3-K pathway and of the Ras/ERK pathway in neuroprotection by BDNF from glutamate toxicity. The results show that BDNF protects hippocampal neurons at the level or upstream of the activation of caspase-3-like enzymes, by a mechanism involving both signaling pathways.

\section{Results}

\section{BDNF protects cultured hippocampal neurons from glutamate-induced cell death}

Cultured hippocampal neurons were challenged with $125 \mu \mathrm{M}$ glutamate and cell death was accessed by analyzing nuclear morphology, $7 \mathrm{~h}$ after the excitotoxic insult, using the fluorescent dyes Syto-13 and propidium iodide. After the excitotoxic insult with glutamate about $40-45 \%$ of the cells displayed an apoptotic morphology (Figure 1), characterized by chromatin condensation and loss of neurites (not shown). Pre-incubation of the cells with BDNF (Figure 1b) or NT-3 (Figure 1c), for $24 \mathrm{~h}$, before the glutamate insult, reduced the number of apoptotic cells in a dose-dependent manner. BDNF was more efficient in protecting the cells than NT-3 at the maximal concentration used $(200 \mathrm{ng} / \mathrm{ml})$, reducing the toxic effect of glutamate by about $60 \%$. As expected, NGF (20$100 \mathrm{ng} / \mathrm{ml}$ ) did not protect hippocampal neurons from glutamate toxicity, in agreement with the known absence of TrkA receptors in the preparation. ${ }^{26}$

Activation of caspase- 3 is a hallmark of apoptotic cell death and precedes changes in nuclear morphology. ${ }^{27}$ Pre-incubation of hippocampal neurons with Z-DEVD-FMK, a cell permeable irreversible inhibitor of caspase-3-like enzymes, ${ }^{28}$ significantly reduced glutamate-induced cell death (Figure 2a). However, at the maximal concentration used, the caspase inhibitor did not fully protect the cells. In control

Figure 1 BDNF and NT-3, but not NGF, protect hippocampal neurons from glutamate-induced cell death. Hippocampal neurons were treated with NGF (a), BDNF (b) or NT-3 (c), for $24 \mathrm{~h}$, and then challenged with $125 \mu \mathrm{M}$ glutamate for $15 \mathrm{~min}$, in fresh Neurobasal medium containing B27 supplement, and then returned to the original medium. Cell death was accessed $7 \mathrm{~h}$ after the insult by fluorescence microscopy, using the fluorescence dyes Syto-13 and PI. Control cells were incubated for $15 \mathrm{~min}$, with fresh glutamate-free Neurobasal medium containing B27 supplement, and were then returned to the original culture medium. Data are presented as the mean + s.e.m. of the indicated number of experiments, performed in independent preparations. ${ }^{* * *} P<0.001$ as compared with control cells; ${ }^{++}+P<0.001$ as compared with cells stimulated with glutamate alone experiments hippocampal neurons were treated only with the caspase inhibitor (50-100 $\mu \mathrm{M})$, and no toxicity was observed.

To further confirm that in our model system glutamate induced an apoptotic-like form of neuronal cell death, we
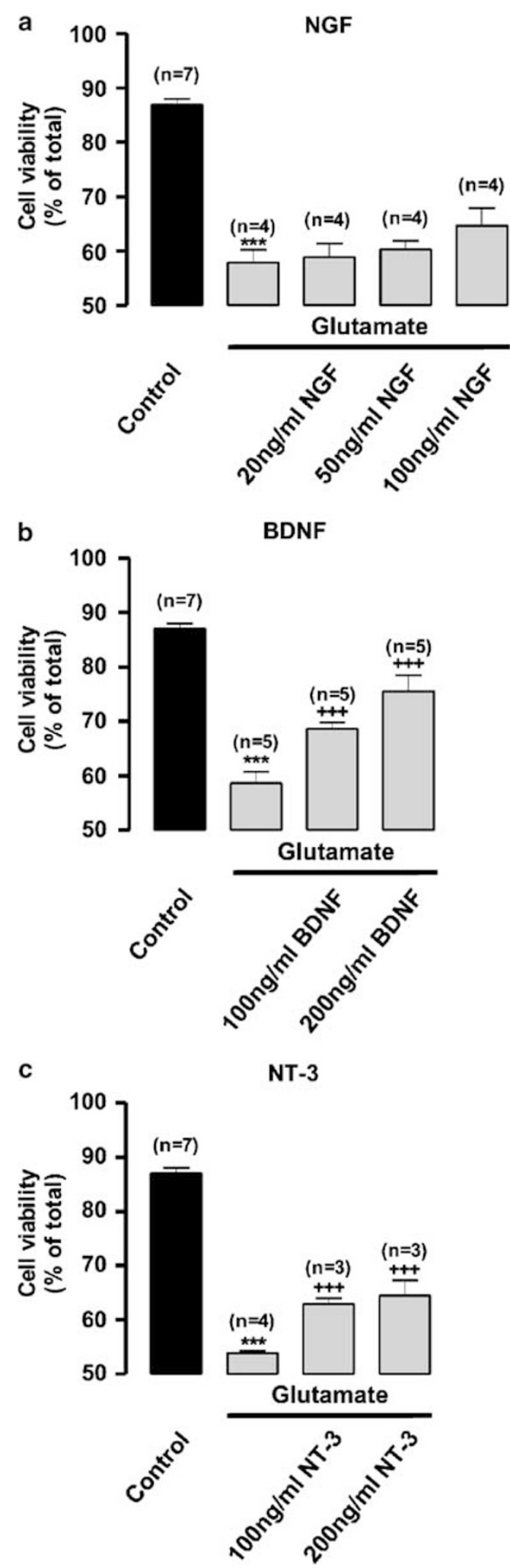


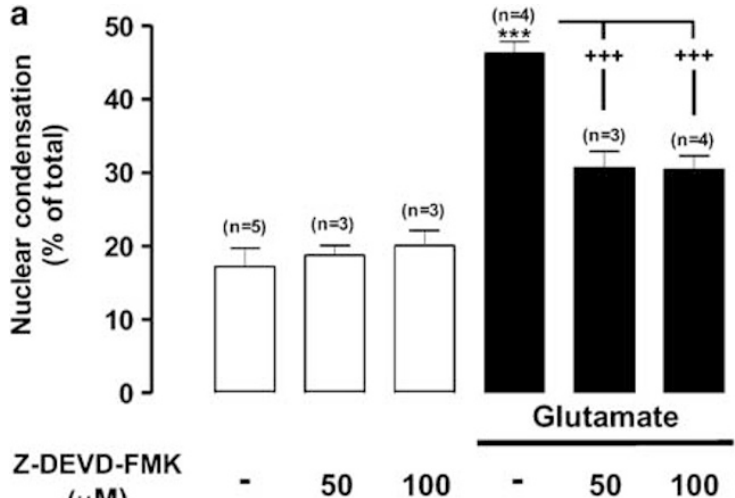
$(\mu \mathrm{M})$

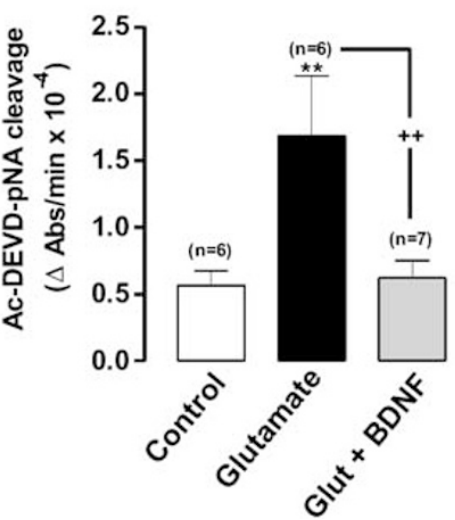

Figure 2 BDNF inhibits caspase-3-like activity induced by glutamate. (a) Hippocampal neurons were challenged with $125 \mu \mathrm{M}$ glutamate, for $15 \mathrm{~min}$, in the presence or absence of the indicated concentrations of the caspase-3 like inhibitor Z-DEVD-FMK. Control cells were incubated with the inhibitor alone, at the indicated concentrations, and no toxicity was observed. The experiments were conducted as described in the caption of Figure 1 and cell death was assessed $7 \mathrm{~h}$ after the insult. (b) Hippocampal neurons were treated or not with $100 \mathrm{ng} / \mathrm{ml} \mathrm{BNDF}$, for $24 \mathrm{~h}$, and challenged with $125 \mu \mathrm{M}$ glutamate or not (control), for $15 \mathrm{~min}$. Caspase-3-like activity in cellular extracts was assessed $5 \mathrm{~h}$ after the insult by following the cleavage of the Ac-DEVD-pNA substrate. Data are presented as mean \pm S.E.M. of the indicated number of experiments, performed in independent preparations. ${ }^{* *} P<0.001$ as compared to control; ${ }^{+}+P<0.01$ $+++P<0.001$ as compared with cells stimulated with glutamate alone

measured caspase-3-like activity in extracts prepared from hippocampal cultures treated or not with glutamate, using the chromogenic substrate Ac-DEVD-pNA. The results show that excitotoxic stimulation with glutamate increased caspase-3like activity, but this effect was not observed in cells preincubated with BDNF for $24 \mathrm{~h}$, before the toxic insult. These results indicate that BDNF protects hippocampal neurons at the level or upstream of the activation of caspase-3-like enzymes.

\section{The Ras/MAPK pathway is involved in neuroprotection by BDNF against glutamate toxicity}

Since BDNF was more potent in protecting hippocampal neurons against glutamate toxicity than NT-3, we further investigated the signaling pathways responsible for the effect of the former neurotrophin. Activation of Trk receptors by
BDNF was required for neuroprotection, since no effect of the neurotrophin on glutamate toxicity was observed when the experiments were conducted in the presence of $\mathrm{K} 252 \mathrm{a}$ (200 nM), an inhibitor of this family of receptors ${ }^{29}$ (Figure $3 a$ and b). Control experiments showed that K252a did not affect glutamate toxicity in the absence of BDNF. The effect of K252a on Trk receptors was confirmed by Western blot, using an antibody that recognizes phosphotyrosine 490 in TrkA, a residue conserved in the other Trk receptors. Stimulation of cultured hippocampal neurons with $100 \mathrm{ng} / \mathrm{ml}$ BDNF, for $5 \mathrm{~min}$, increased Trk (presumably TrkB) phosphorylation, and this effect was inhibited by K252a (Figure 3c).

The kinetics of activation of the Ras/ERK pathway by BDNF was followed by Western blot, using an antibody that specifically recognizes the dually phosphorylated (active) form ERK1 and 2. ${ }^{30}$ The activity of ERK 1 and 2 in cultured hippocampal neurons was very low under resting conditions, but it was transiently increased upon stimulation of the cells with $100 \mathrm{ng} / \mathrm{ml}$ BDNF. The kinetics of activation of the two kinases was similar (Figure $4 \mathrm{c}$ and d), although the increase in phospho-ERK2 immunoreactivity was more significant than that obtained for phospho-ERK1 (Figure 4a). The total amount of ERK2 present in the cells was also higher than the expression of ERK1 protein (Figure 4b). The maximal phosphorylation of ERKs was attained after 7.5-10 min of stimulation, and the activity of the kinases decreased afterwards, towards a plateau close to basal levels. After $24 \mathrm{~h}$ stimulation of hippocampal neurons with BDNF, an incubation period that confers neuroprotection (Figure 1), the phosphorylation of ERK1 and 2 was not significantly different from basal phosphorylation $(P>0.05)$.

In order to test if the activation of the ERK pathway was involved in the neuroprotective effect of BDNF, we inhibited pharmacologically MAPK/ERK Kinase (MEK), the upstream kinase of ERK, with PD098059 $(20 \mu \mathrm{M})^{31}$ or U0126 $(300 \mathrm{nM}) .^{32}$ In the presence of the MEK inhibitors, the neuroprotective effect of BDNF against glutamate-evoked cell death was completely abrogated (Figure 5a), as observed by analysis of nuclear morphology, indicating that the ERK pathway mediates the neuroprotective effect of BDNF against glutamate toxicity $(P<0.001)$. When PD098059 and LY294002, a PI3-K inhibitor, were present together, no additive effect was observed. Control experiments revealed that the two MEK inhibitors used were without effect on glutamate toxicity measured in the absence of BDNF (Figure 5b). To test for possible toxic effects of those inhibitors, hippocampal neurons were treated independently with PD098059 or U0126, at the concentration used in this work, and no toxicity was observed (not shown).

The concentrations of the MEK inhibitors used in the present work are below the range of concentrations that fully block the kinase in in vitro assays. ${ }^{33}$ However, we could not use higher concentrations of the antagonists because of their toxic effects. Since the effect of inhibitors of MEK activation in vivo may also depend on how potently the signaling pathway is activated by any particular agonist, ${ }^{31}$ we determined the effect of PD098059 and of U0126 on the phosphorylation of ERK1/2 in hippocampal neurons stimulated with BDNF. The results of Figure 5c show that PD098059 inhibited the phosphorylation of ERK1 and 2 in response to stimulation 
with $100 \mathrm{ng} / \mathrm{ml}$ BDNF by about $65 \%$. U0126 also inhibited the phosphorylation of ERK1 and 2 by about 60 and $20 \%$, respectively.

In order to further confirm the role of the ERK pathway in the neuroprotection by BDNF, we performed experiments transfecting hippocampal neurons with a dominant-negative construct of MEK (MEK KN). ${ }^{34}$ When hippocampal neurons were transfected with the dominant-negative form of MEK, the neuroprotective effect of BDNF was abolished, in agreement with the results obtained with the pharmacological inhibitors (Figure 5d). Control experiments revealed that transfection of hippocampal neurons with the MEK KN does not affect glutamate toxicity measured in the absence of BDNF. The

a
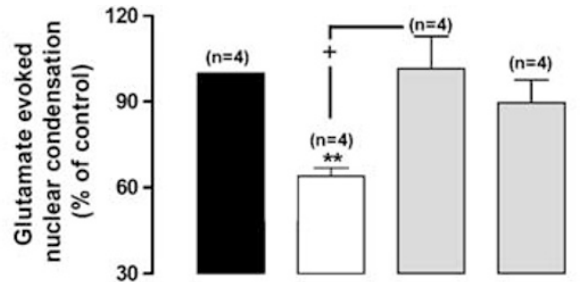

Glutamate $(125 \mu \mathrm{M})$ BDNF $(100 \mathrm{ng} / \mathrm{ml})$

K252a (200 nM)
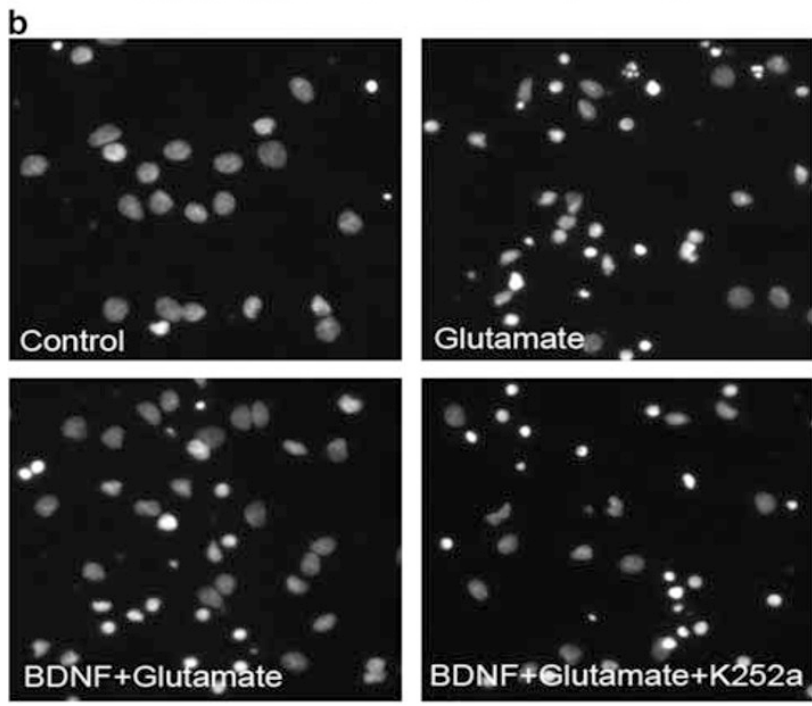

C
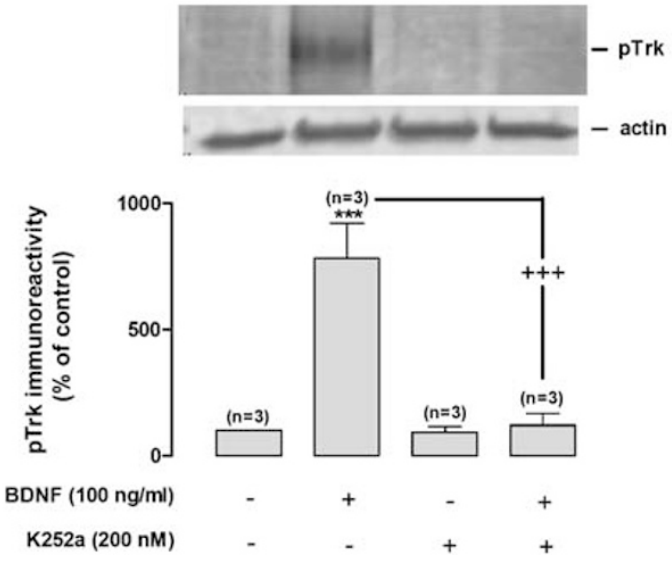

transfection by its own did not induce any toxicity, as well as the transfection of neurons with GFP plus MEK KN or GFP alone (data not shown). Taken together, the results indicate that the ERK pathway mediates the protective effect of BDNF against excitotoxic insults in cultured hippocampal neurons.

\section{The PI3-K/Akt pathway is involved in BDNF neuroprotection against glutamate}

In order to evaluate the effect of BDNF on the PI3-K pathway in cultured hippocampal neurons, we determined the kinetics of phosphorylation of Akt, a kinase that is a downstream effector of PI3-K. Akt is activated by phosphorylation on Thr308, Ser473 and on a tyrosine residue, by different kinases, and phosphorylation of these sites is necessary for full activation of the kinase. ${ }^{35,36}$ Therefore, we assessed the phosphorylation of Akt on Ser473 and on Thr308, by Western blot, as a measurement of the activity of the PI3-K pathway. Under resting conditions there was a basal phosphorylation of Akt on Ser473 (Figure 6b) and on Thr308 (Figure 6c), which contrasts with the low phosphorylation of ERK1/2 shown in Figure 4. Upon stimulation of the cells with BDNF, there was a 2.5-fold increase in the phosphorylation of Akt on Thr308 and a 3.2-fold increase in Ser473 phosphorylation. This increase in Akt activity was transient, peaking after $7.5-10 \mathrm{~min}$ of stimulation, and decreasing afterwards towards a plateau. After $24 \mathrm{~h}$ stimulation of hippocampal neurons with BDNF, an incubation period that leads to neuroprotection against glutamate toxicity (Figure 1), the phosphorylation of Akt was not significantly different from basal phosphorylation $(P>0.05)$.

The role of the PI3-K pathway in the protection by BDNF against glutamate toxicity was investigated using two chemically different inhibitors of the enzyme: wortmannin, a fungal toxin that covalently binds to and blocks the activity of the catalytic p110 subunit of PI3-K, ${ }^{37}$ and LY294002, a synthetic bioflavenoid that reversibly binds to and inhibits $\mathrm{p} 110{ }^{38}$ Preincubation of the cells with LY294002 $(30 \mu \mathrm{M})$ or with

Figure 3 The neuroprotective effect of BDNF is mediated through the activation of Trk receptors. (a) Hippocampal neurons were pretreated or not with the Trk inhibitor, K252a (200 nM), 30 min before they were incubated for $6 \mathrm{~h}$, with $100 \mathrm{ng} / \mathrm{ml}$ BDNF. This pre-incubation period provides maximal protection by BDNF (see Figure 10). The cells were then challenged with glutamate $(125 \mu \mathrm{M})$ during $20 \mathrm{~min}$. Cell death was accessed $14 \mathrm{~h}$ later by fluorescence microscopy, using the fluorescent dye Hoechst 33342. Data are presented as mean \pm S.E.M. of three experiments, performed in independent preparations, and are expressed as a percentage of cell death observed in response to glutamate stimulation alone. ${ }^{* *} P<0.01$ as compared with cells stimulated with glutamate alone; $+P<0.05$. The nuclear morphology of control cells, and the effect excitotoxic stimulation with glutamate, in the presence or in the absence of BDNF, are shown in (b). The inhibition of neuroprotection by BDNF in the presence of K252a is also shown in (b). (c) Hippocampal neurons were pretreated or not with $200 \mathrm{nM}$ $\mathrm{K} 252 \mathrm{a}$, for $30 \mathrm{~min}$, and then incubated with $100 \mathrm{ng} / \mathrm{ml} \mathrm{BDNF}$, for $5 \mathrm{~min}$, with or without the Trk inhibitor. Cells were then lysed and total extracts $(30 \mu \mathrm{g})$ were analysed by Western blot, using an anti-phospho-Trk (phosphotyrosine 490) antibody. Protein loading was checked by stripping and reprobing the membrane with an anti-actin antibody. The immunoreactivity obtained in each experimental condition was calculated as a percentage of the control. The results of a representative experiment are also shown. Data are presented as mean \pm S.E.M. of three different experiments, performed in independent preparations ${ }^{* \star *} P<0.001$ as compared with the control, nonstimulated cells; $+++P<0.001$ 


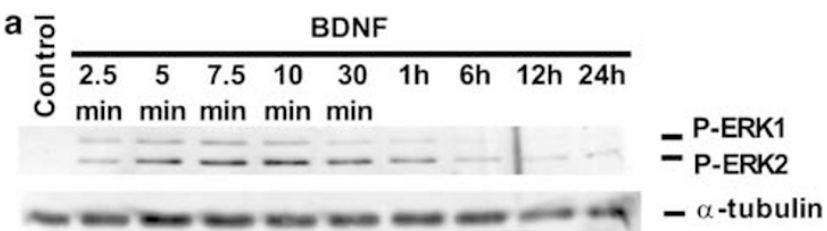

b

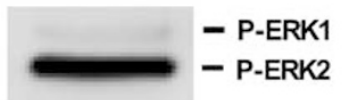

C

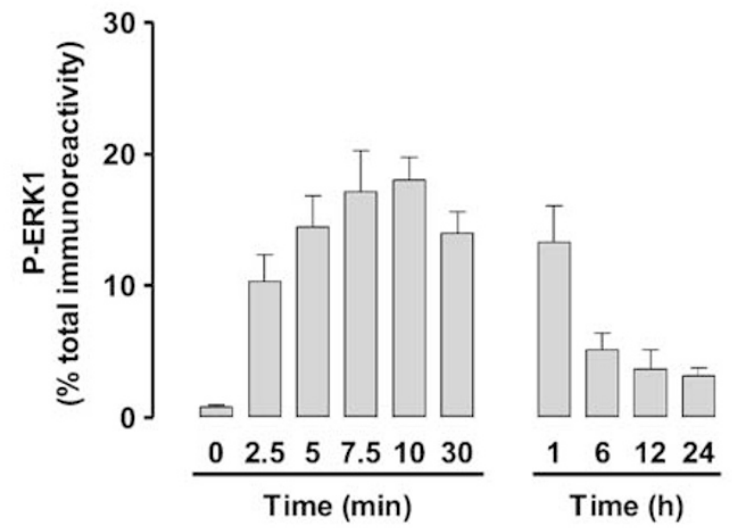

d

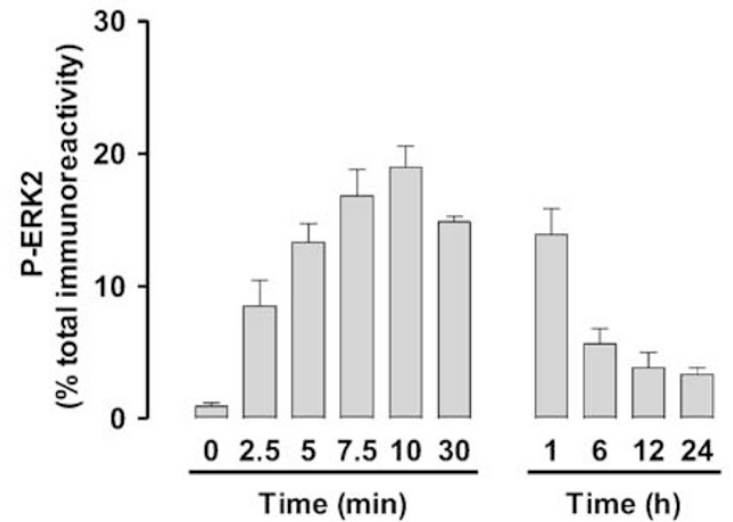

Figure 4 BDNF induces a transient activation of ERK1 and ERK2 in cultured hippocampal neurons. Cellular preparations were treated with $100 \mathrm{ng} / \mathrm{ml}$ BDNF for the indicated time periods and then lysed and analyzed by immunoblot against P-ERK1 and P-ERK2 (a, c and d). Panel (a) shows the result of a representative experiment. In each experimental condition the immunoreactivity obtained was calculated as a percentage of the total signal obtained for the corresponding isoform. Data are presented as mean + S.E.M. of four independent experiments. In (b) nonstimulated cultured hippocampal neurons were lysed and immunobloted using an antibody that recognizes total ERK1/2. The results are representative of three independent experiments

wortmannin $(100 \mathrm{nM})$, before and during stimulation with BDNF, significantly inhibited $(P<0.001)$ the protective effect of the neurotrophin against glutamate-evoked cell death (Figure 7a). In the presence of BDNF and wortmannin or LY294002, cell death induced by glutamate was not significantly different from that evoked by glutamate alone $(P<0.05)$. When PI3-K and MEK were simultaneously inhibited during stimulation of the cells with BDNF, with LY294002 and PD098059, respectively, the toxic effect of glutamate was not different from that observed in the presence of BDNF and with the PI3-K inhibitor alone. Control experiments revealed that the two PI3-K inhibitors used were without effect on the toxicity of glutamate measured in the absence of BDNF (Figure 7b). To test for possible toxic effects of those inhibitors, hippocampal neurons were treated with wortmannin and LY294002 alone, at the concentration used in this work, and no toxicity was observed (not shown).

In order to confirm that the PI3-K inhibitors used indeed affect this signaling pathway at the concentration used, we determined the effect of LY294002 (30 $\mu \mathrm{M})$ and wortmannin $(100 \mathrm{nM})$ on the phosphorylation of Akt on Ser473, in the absence and in the presence of BDNF. Akt phosphorylation at Ser473 was reduced to values below (LY294002) or similar (wortmannin) to those of basal conditions (Figure 7c), confirming that PI3-K pathway was indeed inhibited by the pharmacological compounds used.

To further confirm the role of PI3-K pathway in the neuroprotection by BDNF, we performed experiments transfecting hippocampal neurons with a dominant-negative form of Akt (Akt KN). ${ }^{39}$ Our results show that BDNF neuroprotection was completely prevented when the cells were transfected with a dominant-negative form of Akt (Akt KN) (Figure 7d), confirming the pharmacological data. Control experiments revealed that transfection of hippocampal neurons with Akt KN does not affect glutamate toxicity measured in the absence of BDNF. Neither the transfection process by its own nor GFP induce any toxicity to the neurons (data not shown), but the dominant-negative form of Akt increased basal cell death by about $9 \%$.

\section{PI3-K/Akt cross-talks with Ras/MAPK pathway}

Our results showing that inhibition of PI3-K and MEK affects to the same extent the protection of hippocampal neurons by BDNF against glutamate toxicity may suggest that: (i) the two signaling pathways share a common mechanism of neuroprotection and/or (ii) inhibition of a pathway not involved in neuroprotection leads to the inhibition of the protective pathway. The latter hypothesis suggests that there might be a strong cross-talk between the PI3-K and the MEK pathway. Accordingly, inhibition of the PI3-K and PDK1 has been shown to inhibit the ERK pathway in a cell type- and ligand-specific manner. ${ }^{40-44}$

In order to determine whether the PI3-K pathway controls the activation of ERK1/2 in hippocampal neurons exposed to BDNF, we determined the phosphorylation of the kinase in cells stimulated with the neurotrophin in the presence or absence of PI3-K antagonists. The PI3-K inhibitor LY294002 $(30 \mu \mathrm{M})$ inhibited the phosphorylation of ERK1 and 2 by about $70 \%$, and wortmannin $(100 \mathrm{nM})$ decreased the phosphorylation of ERK 1 and 2 stimulated by BDNF by about 80 and $60 \%$, respectively (Figure 8). As expected, both PI3-K inhibitors were without effect on the phosphorylation of ERK1/2 under resting conditions.

Since the kinetics of activation of the Ras/MAPK pathway and of the PI3-K pathway in hippocampal neurons stimulated with BDNF is very similar, we also investigated a putative effect of MEK on the latter signaling pathway. Inhibition of 

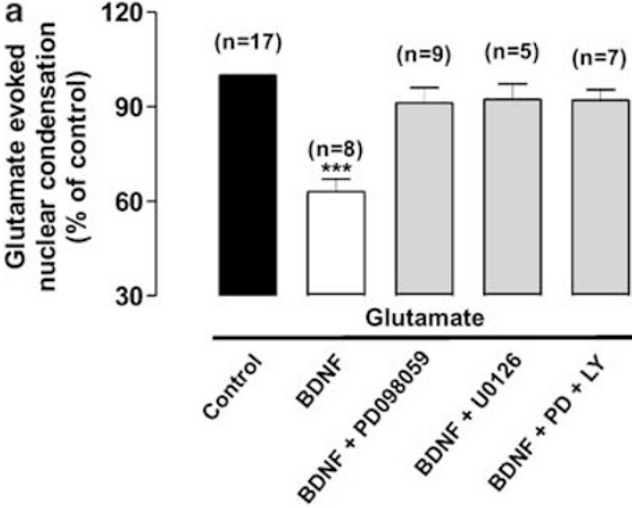

C

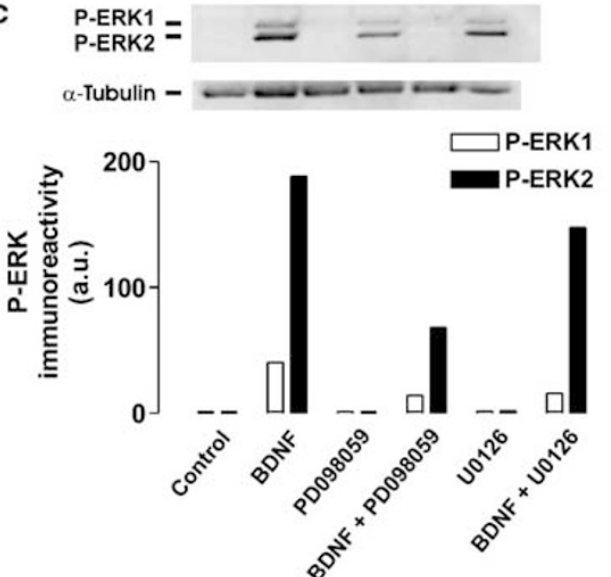

b

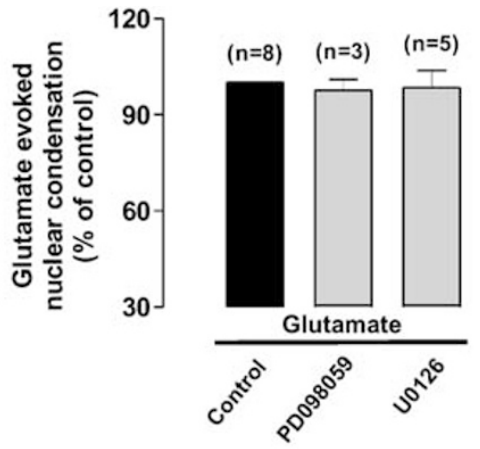

d
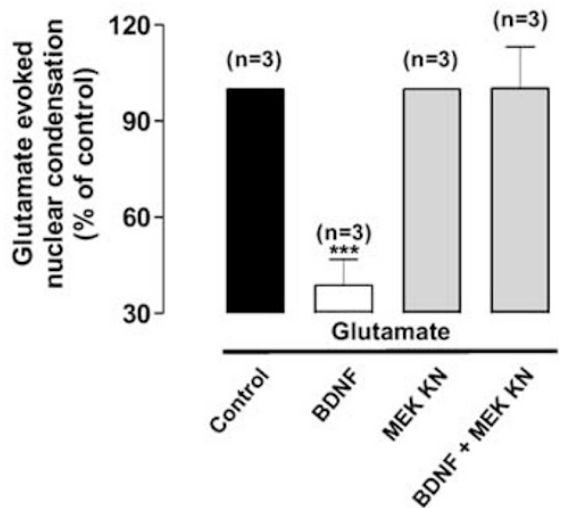

Figure 5 The neuroprotective effect of BDNF is mediated through the Ras/MAPK pathway. Hippocampal neurons were pretreated with the MEK inhibitors, PD098059 $(20 \mu \mathrm{M})$ and $\mathrm{U} 0126(300 \mathrm{nM})$, for $15 \mathrm{~min}$, before they were incubated (a), or not (b), for $24 \mathrm{~h}$, with $100 \mathrm{ng} / \mathrm{ml} \mathrm{BDNF}$, and then challenged with glutamate. Cell death was assessed $7 \mathrm{~h}$ later by fluorescence microscopy using the fluorescence dyes Syto-13 and PI. (c) Hippocampal neurons were pretreated with $20 \mu \mathrm{M}$ PD098059 or $300 \mathrm{nM}$ U0126, for $15 \mathrm{~min}$, and then incubated with BDNF, for $7.5 \mathrm{~min}$, with or without MEK inhibitors. Cells were lysed and total cell extracts (12.5 $\mu \mathrm{g}$ protein) were analyzed by Western blot using an anti-phospho-ERK1/2 antibody. Protein loading was checked by stripping and reprobing the membrane with an anti-tubulin ( $\alpha$-tubulin) antibody. The data are representative of three independent experiments. In (d), hippocampal neurons were co-transfected with a dominant-negative construct of MEK (MEK KN) and GFP, for $24 \mathrm{~h}$, in a proportion $5: 1$, respectively, and then treated with $100 \mathrm{ng} / \mathrm{ml} \mathrm{BDNF}$. After $24 \mathrm{~h}$ incubation with BDNF, the cells were challenged with glutamate and death of GFP-positive neurons was assessed $14 \mathrm{~h}$ later by fluorescence microscopy, using the fluorescent dye Hoechst 33342 . Data are presented as mean \pm S.E.M. of the indicated number of experiments, performed in independent preparations, and are expressed as a percentage of cell death, by apoptosis, observed in response to glutamate stimulation alone. ${ }^{* * *} P<0.001$ as compared to glutamate-induced cell death

MEK with PD098059 or with U0126 during stimulation of hippocampal neurons with BDNF had a minor effect on the activation of the PI3-K pathway, as determined by the phosphorylation of Akt on Ser473. Furthermore, both inhibitors were without effect on the phosphorylation of the kinase on Ser473 under resting conditions (Figure 8b). Therefore, the results indicate that the $\mathrm{PI} 3-\mathrm{K}$ pathway contributes to the activity of the Ras/MAPK pathway in hippocampal neurons stimulated with BDNF.

\section{BDNF does not downregulate glutamate-evoked activation of the p38 MAPK and C-Jun N-terminal kinase (JNK) signaling pathways}

Recent studies showed that activation of the p38 MAPK mediates glutamate-induced apoptotic death of cultured cerebellar granule neurons. ${ }^{45,46}$ Excitotoxic stimulation of glutamate receptors was also shown to activate JNK, and this pathway may also contribute to cell death. ${ }^{45,47,48}$ Therefore, we investigated whether a downregulation of p38 MAPK and/ or JNK signaling pathways could account for neuroprotection by BDNF. Stimulation of cultured hippocampal neurons with glutamate induced a transient phosphorylation of p38 MAPK (Thr180/Tyr182), with a maximal effect at 5 min (not shown). However, the effect of glutamate was not significantly different in cells pre-incubated with BDNF for $24 \mathrm{~h}$ (Figure 9a). In addition to p38 MAPK, there was also a transient increase in the phosphorylation of a JNK isoform (Thr183/Tyr185), with an apparent molecular mass of $46 \mathrm{kDa}$, in hippocampal neurons stimulated with glutamate. The maximal effect was observed after $5 \mathrm{~min}$ of stimulation with glutamate (not shown), and the phosphorylation (activation) of this JNK isoform was not affected in cells pre-incubated with BDNF for $24 \mathrm{~h}$ (Figure 9b). The antibody used also recognized two other bands, with a higher apparent molecular mass, whose immunoreactivity did not change in response to glutamate stimulation. These results indicate that the protection by 
a
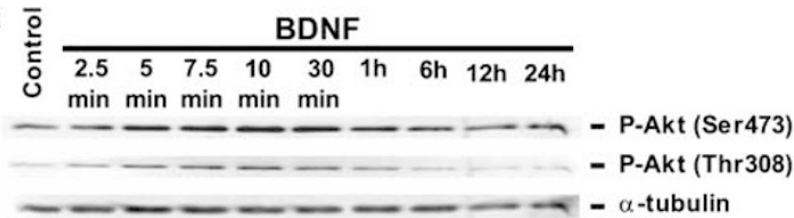

b

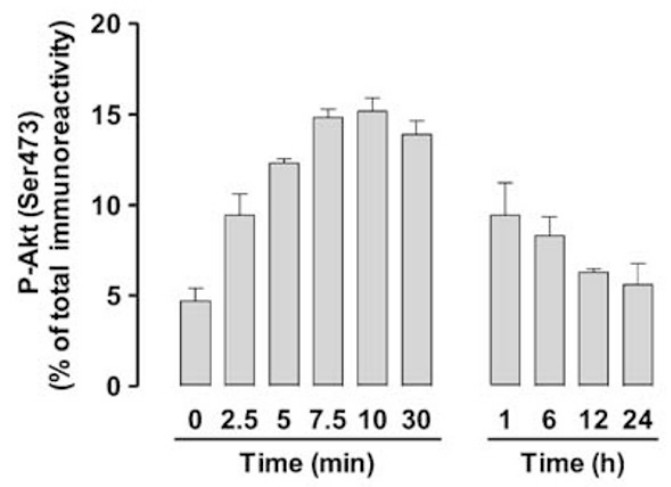

C

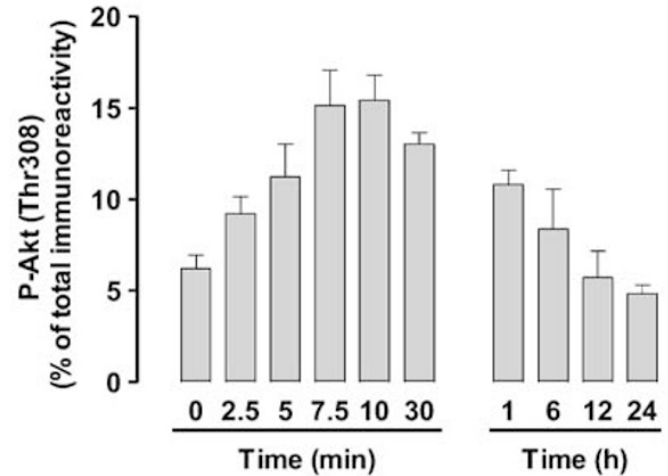

Figure 6 BDNF induces a transient activation of Akt in cultured hippocampal neurons. Cellular preparations were treated with $100 \mathrm{ng} / \mathrm{ml}$ BDNF for the indicated time periods and then lysed and analyzed by immunoblot against P-Akt (Ser473) (a and $\mathbf{b})$. The membranes were then stripped and reprobed against P-Akt (Thr308) (a and c). Protein loading (12.5 $\mu$ g protein) was checked by stripping and reprobing the membrane with an anti-tubulin ( $\alpha$-tubulin) antibody. Panel (a) shows the result of a representative experiment. In each experimental condition the immunoreactivity obtained was calculated as a percentage of the total signal obtained for P-Akt (Ser473) (b) or P-Akt (Thr308) (c). Data are presented as mean \pm S.E.M. of four independent experiments

BDNF under excitotoxic conditions is not due to an effect on the activation of stress-activated protein kinases.

\section{The neuroprotective effect of BDNF is protein synthesis dependent}

Considering that the BDNF treatment induces a rapid and transient activation of both ERK and Akt, and that the neuroprotective effect of BDNF in the experiments reported above was observed after a $24 \mathrm{~h}$ incubation period, we hypothesized that neuroprotection by BDNF could be due to a change in transcription and/or translation. Since long (24 h) incubations with transcription or translation inhibitors are toxic to hippocampal neurons, we determined the effect of anisomycin, an inhibitor of protein synthesis, on the protection by BDNF, using $6 \mathrm{~h}$ pre-incubation with the neurotrophin.
Figure 10a shows that the maximal neuroprotection by BDNF was already observed at this period of incubation. When hippocampal neurons were pre-incubated with anisomycin, together with BDNF, the neuroprotection by the neurotrophin was completely blocked (Figure 10b). Control experiments showed that $5 \mu \mathrm{M}$ anisomycin fully inhibited the incorporation of $\left[{ }^{32} \mathrm{~S}\right]$ cysteine and $\left[{ }^{32} \mathrm{~S}\right]$ methionine into proteins in cultured hippocampal neurons (not shown). Also, incubation of the cells with anisomycin $(5 \mu \mathrm{M})$, during a period corresponding to the total duration of the experiments, did not affect cell viability, as determined by fluorescence microscopy, using the fluorescent dye Hoechst 33342 (not shown). Our data indicate that BDNF neuroprotective effect against glutamate toxicity is mediated through a protein synthesis-dependent mechanism.

\section{BDNF increases $\mathrm{Bcl}-2$ protein levels in cultured hippocampal neurons}

The $\mathrm{Bcl}-2$ family proteins are key players in modulating neuronal survival and death. ${ }^{49}$ We hypothesized that the protein synthesis-dependent neuroprotective effect of BDNF could be due to a change in the abundance of an antiapoptotic member of this family of proteins. Cells were treated with $\mathrm{BDNF}$, for $24 \mathrm{~h}$, and $\mathrm{Bcl}-2, \mathrm{Bcl}-\mathrm{x}_{\mathrm{L}}$, Bad and Bax protein levels were analyzed in cultured hippocampal neurons by Western blot. Our results indicate that BDNF significantly increased the abundance of $\mathrm{Bcl}-2$ (Figure 11) in hippocampal neurons when compared to control cells $(P<0.01)$, to about $124 \%$ of the control. In contrast, $\mathrm{Bax}, \mathrm{Bcl}-\mathrm{x}_{\mathrm{L}}$ and Bad protein levels were not altered under the same experimental conditions (Figure 11). Taken together, our results suggest that Bcl-2 may mediate, to some extent, the long-term protective effects provided by BDNF against glutamate toxicity.

\section{Discussion}

In this work, we have shown that pre-incubation with BDNF or NT-3 protects cultured hippocampal neurons against glutamate toxicity, by acting at the level or upstream of the activation caspase-3-like enzymes. Neuroprotection by BDNF was mediated through a transient activation of the Ras/MAPK pathway and of the PI3-K/Akt pathway, which was detected by the phosphorylation of its mediators ERK $1 / 2$ and Akt, respectively. Blocking each of these pathways, with specific pharmacological inhibitors or with dominant-negative constructs of MEK and Akt, prevented the neuroprotective effect of BDNF. Our results also show that de novo protein synthesis is required for neuroprotection by BDNF and, accordingly, incubation of hippocampal neurons with the neurotrophin increased Bcl-2 protein levels. The effects of BDNF and NT-3 observed in the present work are in agreement with the reported presence of TrkB and TrkC receptors in the hippocampus from early in development, ${ }^{50-52}$ in contrast with the lack of TrkA receptors. ${ }^{26}$ Accordingly, pre-incubation of hippocampal neurons with NGF did not affect glutamate toxicity.

In ischemia and hypoxia, the massive release of glutamate induces neuronal injury of the neuronal population in the area of insult, but the mode of cell death (apoptosis 

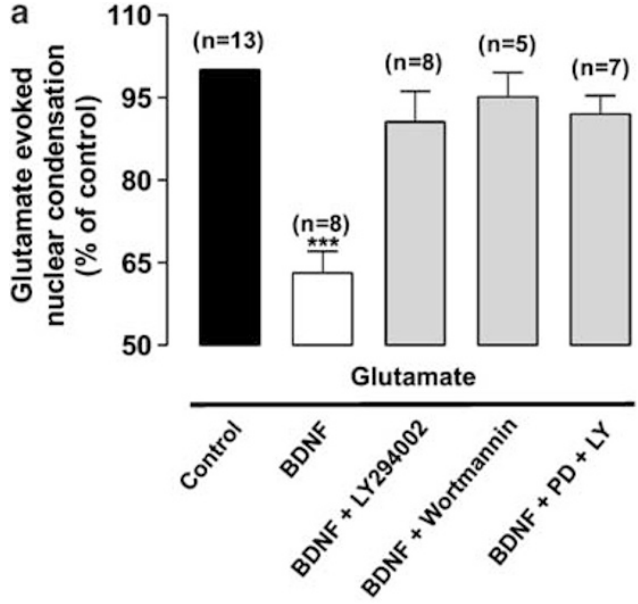

C
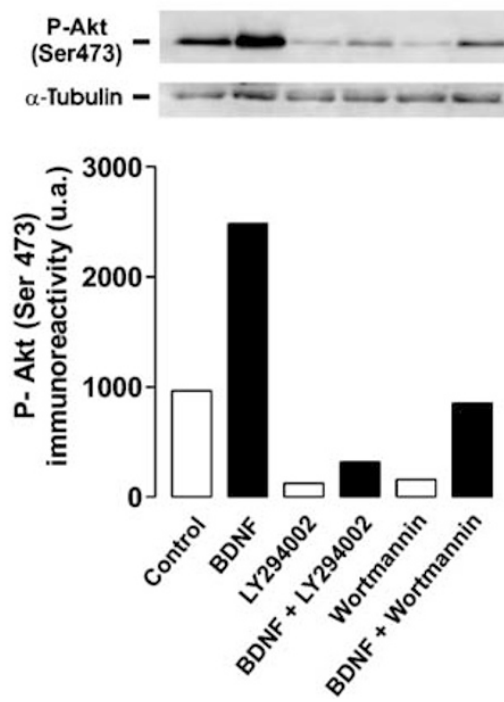

b

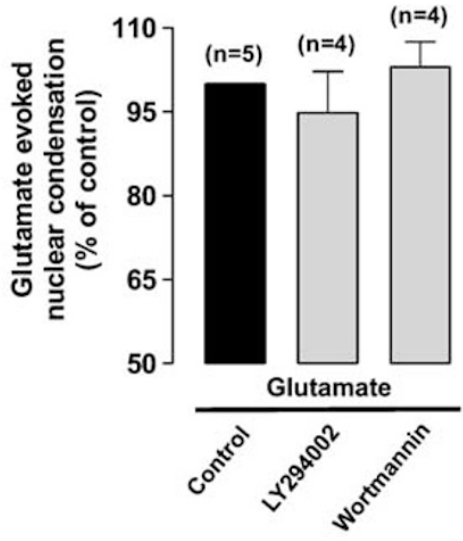

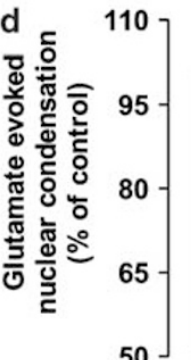

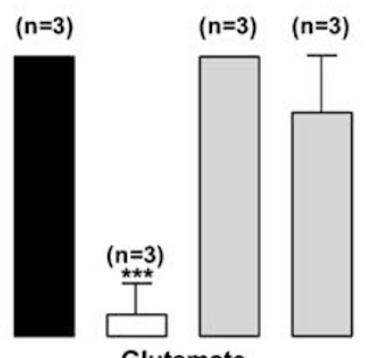

Glutamate

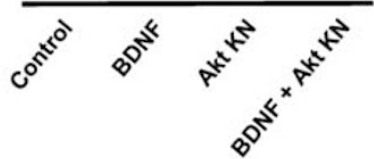

Figure 7 The neuroprotective effect of BDNF is mediated through the PI3-K/Akt pathway. Hippocampal neurons were pretreated with the PI3-K inhibitors, LY294002 $(30 \mu \mathrm{M})$ or wortmannin $(100 \mathrm{nM}), 15 \mathrm{~min}$ before they were incubated $(\mathbf{a})$, or not $(\mathbf{b})$, for $24 \mathrm{~h}$, with $100 \mathrm{ng} / \mathrm{ml}$ BDNF. The cells were then challenged with glutamate and cell death was accessed $7 \mathrm{~h}$ later by fluorescence microscopy, using the fluorescence dyes Syto-13 and PI. (c) Hippocampal neurons were pretreated with $30 \mu \mathrm{M} \mathrm{LY} 294002$ or $100 \mathrm{nM}$ wortmannin, for $15 \mathrm{~min}$, and then incubated with BDNF, for $7.5 \mathrm{~min}$, with or without PI3-K inhibitors. Cells were lysed and total cell extracts were analyzed by Western blot, using an anti-phospho-Akt (Ser473) antibody. Protein loading was checked by stripping and reprobing the membrane with an anti-tubulin ( $\alpha$-tubulin) antibody. The data are representative of three independent experiments. In (d), hippocampal neurons were co-transfected with a dominant-negative construct of Akt (Akt KN) and GFP (5:1), for $24 \mathrm{~h}$, and then treated with $100 \mathrm{ng} / \mathrm{ml} \mathrm{BDNF}$, for $24 \mathrm{~h}$. After incubation with BDNF the cells were challenged with $125 \mu \mathrm{M}$ glutamate, for $20 \mathrm{~min}$, and death of GFP-positive neurons was assessed $14 \mathrm{~h}$ later, by fluorescence microscopy, using the fluorescent dye Hoechst 33342 . Data are presented as mean + S.E.M. of the indicated number of experiments, performed in independent preparations, and are expressed as a percentage of cell death, by apoptosis, observed in response to glutamate stimulation alone. Akt KN increased basal cell death by about $9 \%$; subtraction of basal death and normalization to $100 \%$ cell death in the glutamate treated-only condition overcame this problem. ${ }^{\star \star *} P<0.001$ as compared to glutamate-induced cell death

versus necrosis) changes during development ${ }^{53}$ and depends on the extent of the insult. ${ }^{54}$ In the present work, we showed that BDNF promotes survival of cultured hippocampal neurons under excitotoxic conditions, where cell death occurs by apoptosis. Glutamate-induced cell death was partially prevented by Z-DEVD-FMK, and the cleavage of Ac-DEVD-pNA, a substrate of caspase-3-like enzymes, was completely abrogated in extracts prepared from neurons pre-treated with BDNF, for $24 \mathrm{~h}$, before the excitotoxic insult (Figure 2). The protective effect of BDNF observed in this work, mediated by the activation of Trk receptors, contrasts with the toxicity of neurotrophins in cultured cerebrocortical ${ }^{55}$ and hippocampal neurons. ${ }^{56}$ In the latter study, neurotrophins targeted mainly a subpopulation of neurons that express $p 75$ receptors and lack Trk neurotrophin receptors. Since the majority of hippocampal neurons present in the cultures used in this work express Trk receptors (not shown), in agreement with previously reported results showing that about $90 \%$ of cultured hippocampal neurons express these receptors, ${ }^{52}$ this may account for the apparent discrepancy between our findings and the results reported by Friedman ${ }^{56}$ This difference in the expression of Trk receptors may be due to developmental changes in the abundance of the receptors, since we have used 7-8 DIV cells and neurotrophin toxicity was observed in five DIV neurons. Differences in the composition of the culture medium may 


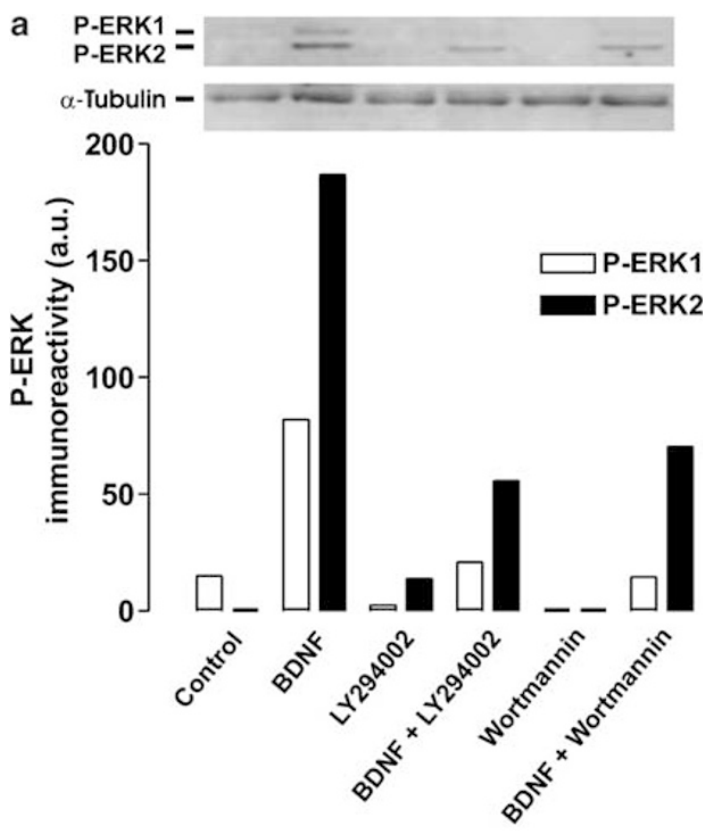

b
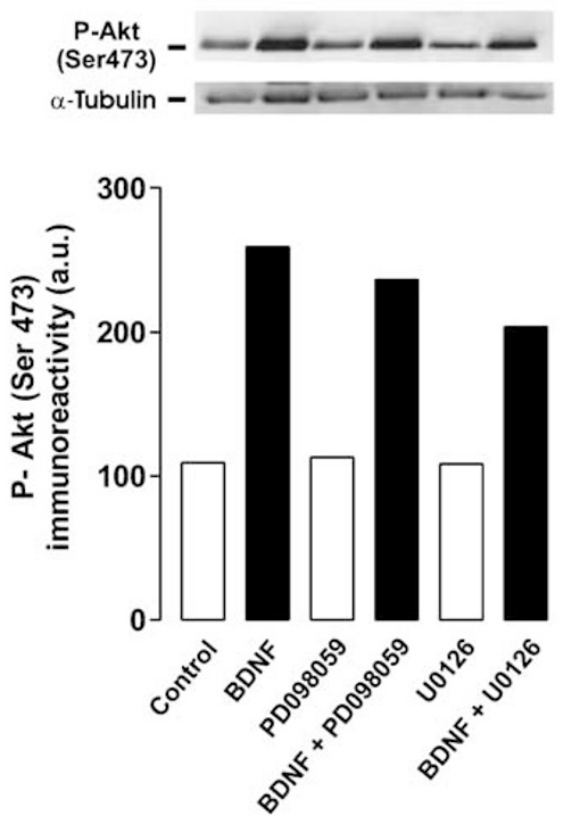

Figure 8 Cross-talk between the PI3-K/Akt pathway and the Ras/MAPK pathway. (a) Hippocampal neurons were pretreated with vehicle, $30 \mu \mathrm{M}$ LY294002 or $100 \mathrm{nM}$ wortmannin, for $15 \mathrm{~min}$, and then with $100 \mathrm{ng} / \mathrm{ml} \mathrm{BDNF}$, for $7.5 \mathrm{~min}$, with or without PI3-K inhibitors. In the control experiments the cells were maintained in the absence of BDNF, without (control) or with inhibitors, for the same period of time. Cells were lysed and total cell extracts were analyzed by Western blot, using an anti-phospho-ERK1/2 antibody. (b) Hippocampal neurons were pretreated with vehicle, $20 \mu \mathrm{M}$ PD098059 or $300 \mathrm{nM}$ U0126, for $15 \mathrm{~min}$, and then with $100 \mathrm{ng} / \mathrm{ml} \mathrm{BDNF}$, for $7.5 \mathrm{~min}$, with or without MEK inhibitors. In the control experiments the cells were maintained in the absence of BDNF, in culture medium lacking (control) or containing the inhibitors, for the same period of time. Cells were lysed and total cell extracts were analyzed by Western blot, using an anti-phospho-Akt (Ser473) antibody. Protein loading was checked by stripping and reprobing the membranes with an anti-tubulin ( $\alpha$-tubulin) antibody. Quantification of the immunoreactivity is shown in the lower panels. Data are representative of three independent experiments a

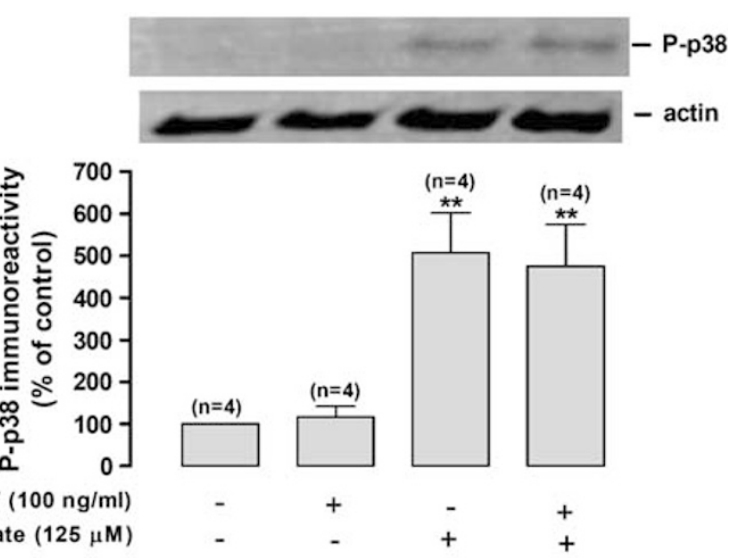

b

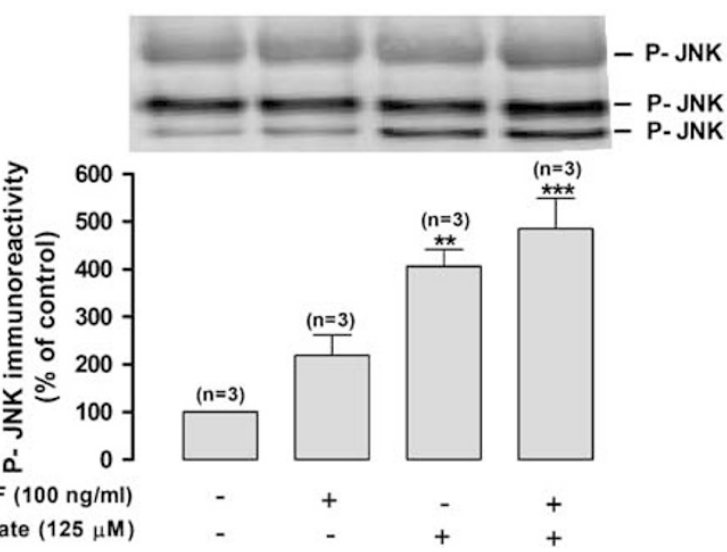

Figure 9 BDNF does not prevent the glutamate-evoked activation of JNK and p38 MAPK. Hippocampal neurons were incubated or not with $100 \mathrm{ng} / \mathrm{ml}$ BDNF, for $24 \mathrm{~h}$, and then challenged with glutamate $(125 \mu \mathrm{M})$, for $5 \mathrm{~min}$. Cells were then lysed and analyzed by immunoblot against phospho-p38 (Thr180/Tyr182) (a), and P-JNK (Thr183/Tyr185) (b). In (A) protein loading (30 $\mu \mathrm{g})$ was checked by stripping and reprobing the membrane with an anti-actin antibody. In (b), the lack of change in immunoreactivity in the heavier bands was used as a loading control. In each experimental condition the immunoreactivity obtained was calculated as a percentage of the control. The immunoblots show representative experiments. Data are presented as mean \pm S.E.M. of 3-4 different experiments, performed in independent preparations. ${ }^{* *} P<0.01$ and ${ }^{* * *} P<0.001$ as compared with control nonstimulated cells

also explain the discrepancy in the effect of neurotrophins in cultured hippocampal neurons.

The transient phosphorylation (activation) of ERK $1 / 2$ in hippocampal neurons stimulated with BDNF, observed in the present work, is in agreement with previous findings in the same preparation, ${ }^{52}$ and with the relatively fast rate of desensitization of TrkB receptors. ${ }^{57} \mathrm{~A}$ downregulation of TrkB receptors under sustained exposure to BDNF may also account for the transient phosphorylation (activation) of Akt, which followed a kinetics similar to that observed for ERK $1 / 2$ phosphorylation. The main difference between the two pathways was that Akt phosphorylation was already significant under resting conditions. This is in agreement with the fundamental role played by Akt in neuronal survival (reviewed by Downward ${ }^{15}$ ), although the kinase is probably not the only target of the PI3-K-induced survival activity. ${ }^{58,59}$

The mechanism by which BDNF exerts its neuroprotective role is still controversial, and may depend on the insult. We have found that the pharmacological inhibitors of MEK, 


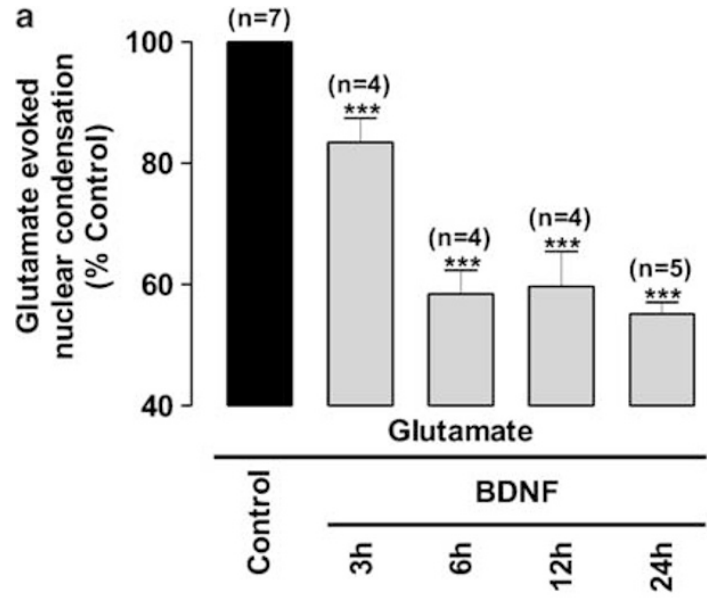

b

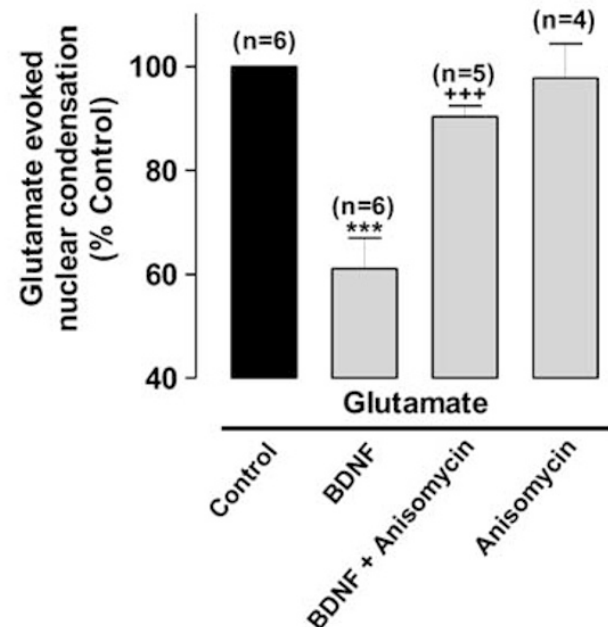

Figure 10 BDNF protects hippocampal neurons against glutamate toxicity through a protein synthesis-dependent mechanism. (a) Cultured hippocampal neurons were pretreated with $100 \mathrm{ng} / \mathrm{ml} \mathrm{BDNF}$ for the indicated time periods and then challenged with $125 \mu \mathrm{M}$ glutamate, for $20 \mathrm{~min}$. Cell death was assessed $14 \mathrm{~h}$ after the excitotoxic insult, by looking at nuclear morphology, using the fluorescent dye Hoechst 33342. (b) Cultured hippocampal neurons were pretreated with $5 \mu \mathrm{M}$ anisomycin, for $15 \mathrm{~min}$, and then stimulated or not with $100 \mathrm{ng} / \mathrm{ml} \mathrm{BDNF}$, for $6 \mathrm{~h}$. Cells were then challenged with glutamate, as indicated above, and returned to conditioned medium without anisomycin, in the presence or in the absence of BDNF, as indicated. Cell death was assessed by looking at nuclear morphology, using the fluorescent dye Hoechst 33342. Data are presented as mean + S.E.M. of the indicated number of experiments, performed in independent preparations, and are expressed as a percentage of cell death, by apoptosis, in response to glutamate stimulation alone. ${ }^{* * *} P<0.001$ as compared to glutamate-evoked cell death under control conditions. ${ }^{+++} P<0.001$ as compared to glutamate-induced cell death in the presence of BDNF

PD098059 and U0126, inhibited the neuroprotection provided by BDNF against the glutamate toxicity, and similar results were obtained using a dominant-negative form of MEK. Similarly, LY294002 and Wortmannin, two distinct inhibitors of PI3-K, abrogated BDNF protection of hippocampal neurons and transfection experiments with a dominant-negative form of Akt confirmed the pharmacological data. The participation of the PI3-K pathway, together with the MEK/ERK pathway, as a survival mechanism stimulated by BDNF in cultured hippocampal neurons subjected to an excitotoxic insult contrasts with the relative role of those signaling cascades a
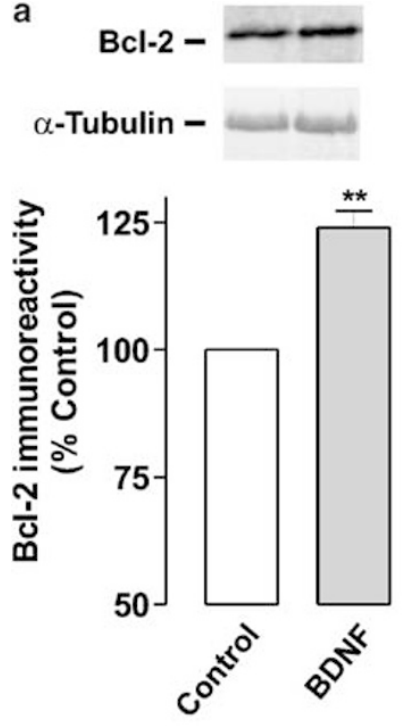

C
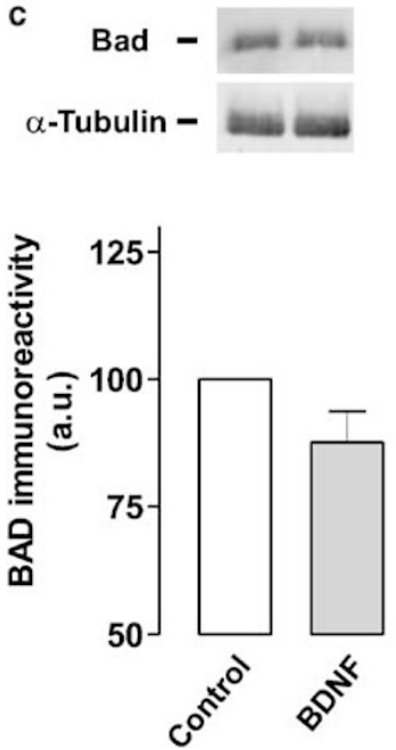

b
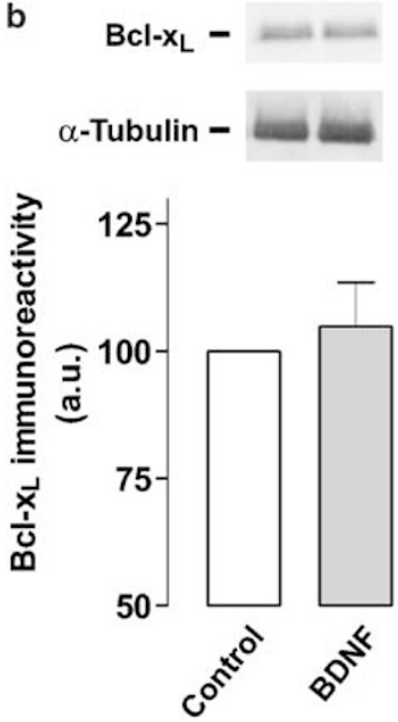

d

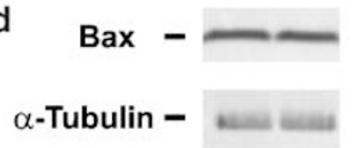

Figure 11 BDNF increases Bcl-2 protein levels in cultured hippocampal neurons. Cultured hippocampal neurons were pretreated with $100 \mathrm{ng} / \mathrm{ml} \mathrm{BDNF}$, for $24 \mathrm{~h}$. Cells were then lysed and total cell extracts were analyzed by Western blot, using antibodies against the indicated proteins of the Bcl-2 family. Protein loading was checked by stripping and reprobing the membranes with an antitubulin ( $\alpha$-tubulin) antibody. The lower panel shows the quantification of the immunoreactivity obtained in the upper panel. Data are the average \pm S.E.M. four independent experiments, performed in independent preparations. In BDNFtreated cultures, the mean Bcl-2 immunoreactivity was $124.0 \pm 3.3 \%(n=4)$ of the control $\left({ }^{* \star} P<0.01\right.$, as determined using the Students $t$-test)

in neuroprotection in studies of neuronal injury from trophic support withdrawal. Indeed, PI3-K was identified as the major regulator of neurotrophin-mediated survival responses in NGF-dependent PC12 cells, ${ }^{60}$ and in cerebellar, ${ }^{61}$ cortical, ${ }^{62}$ sympathetic, ${ }^{63-65}$ sensory ${ }^{66}$ and motor neurons. ${ }^{67}$ In contrast, the MEK/ERK pathway does not contribute or plays a minor role in NGF-dependent survival of PC12 cells ${ }^{68}$ and sensory neurons, ${ }^{64,65}$ and in the BDNF-dependent survival of cerebellar granule neurons. ${ }^{34,69}$ This signaling pathway plays a 
major role in the protective effect of BDNF against DNAdamaging agents in cerebrocortical neurons ${ }^{62}$ and against in vivo hypoxic-ischemic brain injury. ${ }^{70}$ The Ras/ERK pathway stimulated by NGF also inhibits apoptotic death of sympathetic neurons subjected to cytosine arabinoside. ${ }^{65}$ These findings suggest that the major role of MEK/ERK is to protect neurons from death due to injury or toxicity. The fact that both the MEK/ERK and the PI3-K contribute to the protection of hippocampal neurons by BDNF from glutamate toxicity may be explained by the activation of multiple lethal reactions during excitotoxic cell death. ${ }^{71,72}$ After hypoxia-ischemia, there is an increase in double-stained cells for $p$-ERK and p-Akt in the ischemic penumbra (IP), where cells die mainly by apoptosis, in contrast to the ischemic core (IC), which suggests a cooperative role of both signals for survival in the IP. ${ }^{73}$

The simultaneous contribution of the PI3-K and MEK/ERK to the protection of hippocampal neurons by BDNF from glutamate-evoked apoptotic death may also be due to the cross-talk between the two pathways. Indeed, when the effect of BDNF on ERK1/2 phosphorylation was assessed in the presence of LY294002 or wortmannin, we observed a potent decrease in the activation of the kinases. These results indicate that the PI3-K/Akt pathway contributes to the activation of the Ras/MAPK pathway, in agreement with a recent report showing that PDK1 directly binds and activates MEK, therefore contributing to the activation of this pathway. ${ }^{40}$ $\mathrm{PI} 3-\mathrm{K}$ is also responsible for maintaining constitutive ERK1/2 activity in different cell lines, where basal PI3-K and ERK activities are required to prevent cell death. ${ }^{74}$ Other studies have shown that the effect of PI3-K on the Ras/MAPK pathway may occur both upstream of Ras and between Ras and ERK2. ${ }^{41-44,75}$ In contrast, Akt phosphorylates Raf-1 on Ser-259 and negatively controls its activity in MCF-7 cells stimulated with high but not with low doses of mitogenic stimuli, suggesting that the Raf-Akt cross-talk is regulated in a concentration- and ligand-dependent manner. ${ }^{76}$ The cell type and ligand specificities of the effects of PI3-K inhibitors on MEK/ERK activity, and the fact that a similar inhibition was observed in the present work with two chemically distinct compounds, strongly suggest that this is a specific effect. The differences observed in the cross-talk between the Ras/ MAPK and PI3-K/Akt pathways in distinct models could therefore be due to differences in the type and dose of the agonist and in the cellular background used.

In addition to the cross-talk between the Ras/MAPK and the PI3-K pathways that may account for their role in neuroprotection by BDNF under excitotoxic conditions, the results are also compatible with a role for a common mechanism acting downstream of the two pathways. Accordingly, the Ras/MAPK and the PI3-K pathways are known to stimulate the serum response factor (SRF), which plays a role in neuronal survival. $^{77}$

Neurotrophins activate other transcription factors, which can also upregulate the expression of several target genes. Akt was also shown to inhhibit Forkhead transcription factors, inhibiting their ability to induce the expression of death genes. Furthermore, Akt may also induce the expression of survival genes ( $\mathrm{Bcl}-2, \mathrm{BCl}-x_{L}$, and several inhibitor of apoptosis proteins), by activating cAMP response-element binding protein (CREB) and nuclear factor- $\kappa \mathrm{B} .{ }^{15}$ BDNF also upregulates the antioxidant defenses in cultured hippocampal neurons by a still unknown mechanism. ${ }^{17}$ We showed that anisomycin, a protein synthesis inhibitor, completely blocked the neuroprotective effect of BDNF in cultured hippocampal neurons. In agreement with the role of protein synthesis and the Ras/MAPK and PI3-K signaling pathways in neuroprotection by BDNF reported here, chemical inhibitors of PI3-K and MEK fully blocked protein synthesis induced by BDNF in cultured cerebrocortical neurons. ${ }^{78}$

We also showed that upon treatment with $100 \mathrm{ng} / \mathrm{ml} \mathrm{BNDF}$, for $24 \mathrm{~h}, \mathrm{Bcl}-2$ protein levels were increased when compared to the control, suggesting that this protein may be, at least in part, responsible for the protection by the neurotrophin. This is in agreement with a previous report ${ }^{79}$ where NGF-mediated survival of sympathetic neurons was shown to be mediated by a mechanism requiring CREB family transcription factors and $\mathrm{Bcl}-2$ expression. Although the levels of the other Bcl-2 family members tested, Bcl- $x_{\mathrm{L}}$, Bad and Bax, were not altered in hippocampal neurons stimulated with BDNF for $24 \mathrm{~h}$, we cannot exclude the possibility that BDNF may have also prevented the translocation from the cytoplasm to the mitochondria of proapoptotic proteins, such as Bad, Bax and Bak. Pre-incubation of hippocampal neurons with BDNF, for $24 \mathrm{~h}$, did not affect glutamate-induced phosphorylation of JNK and p38 MAPK. Therefore, although these stress-activated kinases have been shown to contribute to apoptotic cell death, by upregulating proapoptotic $\mathrm{BH} 3-o n l y ~ B c l-2$ family members (e.g., Whitfield et al. ${ }^{80}$ ), BDNF is unlikely to modulate this death pathway under the experimental conditions used in this work. Recent studies have shown that activation of TrkB receptors elicits a complex program of changes in gene expression, ${ }^{81}$ which will cause multiple changes in the proteome. Therefore, in addition to $\mathrm{Bcl}-2$, other proteins are likely to contribute to neuroprotection by BDNF under excitotoxic conditions.

Although neurotrophic factors protect CNS neurons from excitotoxic injury, their clinical use is made difficult due to several drawbacks that generally affect large polypeptides applied as drugs. Therefore, there is currently an active search for delivery strategies of neurotrophic factors and for neurotrophic factor mimetics. ${ }^{82,83}$ A strategy that could be envisaged is based on agents that selectively target the signaling pathways that contribute to neuroprotection from the excitotoxic injury. The results reported here suggest that agents that selectively target the PI3-K and/or the MEK/ERK pathways may be clinically useful in the protection of neurons from glutamate toxicity.

\section{Materials and Methods}

\section{Materials}

Neurobasal medium, the B27 supplement, trypsin and the plasmid maxiprep system were purchased from GIBCO Invitrogen (Paisley, UK). Nerve growth factor (NGF) was obtained from Alomone (Jerusalem, Israel) and BDNF and NT-3 were kind gifts of Regeneron (Tarrytown, NY, USA). Syto-13 and PI were from Molecular Probes (Leiden, The Netherlands). The anti-active MAPK antibody was from Promega (Madison, WI, USA) and the anti-phospho-Akt (Ser473), anti-phospho-Akt (Thr 308), 
anti-phospho-p38 MAPK, anti-phospho-JNK, anti-Bcl-- $\mathrm{L}_{\mathrm{L}}$, anti-Bad and anti-Bax antibodies were from Cell Signaling Technology (Beverly, MA, USA). The rabbit monoclonal anti-ERK1/2 antibody (MK12) was from BD Biosciences (San Jose, CA, USA). The anti-Bcl-2 and the anti- $\alpha$-tubulin antibodies were from Zymed (San Francisco, CA, USA), and the mouse anti-actin antibody was from Chemicon (Temecula, CA, USA). The rabbit anti-phospho-TrkA (phosphotyrosine 490) antibody was from Sigma Chemical Co. (St. Louis, MO, USA). LY294002, wortmannin, PD098 059 and U0126 were purchased from Calbiochem (La Jolla, CA, USA), AcDEVD-pNA was from Bachem (Bubendorf, Switzerland) and Z-DEVDFMK from Enzyme Systems Products (Livermore, CA, USA). Reagents used in immunoblotting experiments were purchased from Bio-Rad (Hercules, CA, USA), with the exception of the polyvinylidene difluoride (PVDF) membranes, the alkaline phosphatase-linked anti-mouse and anti-rabbit secondary antibodies, and the enhanced chemifluorescence (ECF) reagent, which were obtained from Amersham Biosciences (Buckinghamshire, England). All other reagents were from Sigmal Chemical Co. or from Merck KGaA (Darmstadt, Germany). MEK KN and Akt KN were generously provided by Michael Greenberg (Harvard Medical School and Children's Hospital, Boston, USA).

\section{Preparation and culture of hippocampal neurons}

Primary cultures of rat hippocampal neurons were prepared from the hippocampi of E18-E19 Wistar rat embryos, after treatment with trypsin $\left(0.5 \mathrm{mg} / \mathrm{ml}, 15 \mathrm{~min}, 37^{\circ} \mathrm{C}\right)$ and deoxyribonuclease I $(0.20 \mathrm{mg} / \mathrm{ml})$, in $\mathrm{Ca}^{2+}$. and $\mathrm{Mg}^{2+}$-free Hank's balanced salt solution (HBSS; $137 \mathrm{mM} \mathrm{NaCl}$, $5.36 \mathrm{mM} \mathrm{KCl}, 0.44 \mathrm{mM} \mathrm{KH}_{2} \mathrm{PO}_{4}, 0.34 \mathrm{mM} \mathrm{Na} \mathrm{HPO}_{4} \cdot 2 \mathrm{H}_{2} \mathrm{O}, 4.16 \mathrm{mM}$ $\mathrm{NaHCO}_{3}, 5 \mathrm{mM}$ glucose, supplemented with $0.001 \%$ phenol red, $1 \mathrm{mM}$ sodium pyruvate and $10 \mathrm{mM}$ HEPES, $\mathrm{pH} 7.4) .{ }^{84}$ The hippocampi were then washed in HBSS supplemented with $10 \%$ FCS in order to stop trypsin activity and, after centrifugation at $140 \times g_{\mathrm{av}}$, for $1 \mathrm{~min}$, the cells were mechanically dissociated in HBSS. Hippocampal cultures were maintained in serum-free Neurobasal medium, supplemented with B27 supplement, glutamate $(25 \mu \mathrm{M})$, glutamine $(0.5 \mathrm{mM})$ and gentamicin $(0.12 \mathrm{mg} / \mathrm{ml})$. The cells were kept at $37^{\circ} \mathrm{C}$ in a humidified incubator of $5 \% \mathrm{CO}_{2} / 95 \%$ air, for 7-8 days, the time required for maturation of hippocampal neurons. The glial content of hippocampal cultures maintained in Neurobasal medium, supplemented with B27 supplement, was estimated to be about $0.5 \%$ of the total cell population. ${ }^{85}$

\section{Cell viability experiments}

The cells were cultured for 7 days, on poly-D-lysine-coated glass coverslips, at a density of $45 \times 10^{3} \mathrm{cells} / \mathrm{cm}^{2}$, before pre-incubation, for $24 \mathrm{~h}$, in the presence or in the absence of neurotrophins, added to the culture medium. The neurotrophin stock solutions were prepared in sterile phosphate-buffered saline (PBS). The cells were then incubated with $125 \mu \mathrm{M}$ glutamate in supplemented Neurobasal medium, for $15 \mathrm{~min}$ at $37^{\circ} \mathrm{C}$, in a humidified incubator. After stimulation with glutamate, the cells were further incubated with the original culture medium, containing or not neurotrophins, for $7 \mathrm{~h}$ at $37^{\circ} \mathrm{C}$. Cell viability was then measured by staining with the fluorescent dyes Syto-13 $(1.2 \mu \mathrm{M})$ and propidium iodide $\left(2.9 \mu \mathrm{g} / \mathrm{ml}\right.$ ), in $\mathrm{Na}^{+}$medium (in $\mathrm{mM}: 140 \mathrm{mM}, 5 \mathrm{KCl}, 1 \mathrm{CaCl}_{2}, 1 \mathrm{MgCl}_{2}, 5.5$ glucose, $20 \mathrm{HEPES}$ and $1 \mathrm{NaH}_{2} \mathrm{PO}_{4}, \mathrm{pH} 7.4$ ), for 2-3 min at room temperature. Syto-13 is membrane permeant and stains DNA and RNA of cells with intact plasma membranes. PI is membrane impermeant and stains the nuclei of cells with disrupted plasma membranes. ${ }^{18}$ Cells were visualized on a Nikon Diaphot-TMD fluorescence microscope, using the $\mathrm{OMEGA}^{\mathrm{TM}}$ three-dye filter set XF 63. In the experiments where the effect of
MEK inhibitors or PI-3 inhibitors was investigated, the compounds were added to the culture medium 15 min before stimulation with BDNF.

Alternatively, the cells were incubated with $125 \mu \mathrm{M}$ glutamate in supplemented Neurobasal medium, for $20 \mathrm{~min}$ at $37^{\circ} \mathrm{C}$, in a humidified incubator. After stimulation with glutamate, the cells were further incubated with the original culture medium, containing or not neurotrophins, for $14 \mathrm{~h}$ at $37^{\circ} \mathrm{C}$. Cell viability was then measured by fixing the cells in $4 \%$ paraformaldehyde, for $15 \mathrm{~min}$ at room temperature. Fixed cells were washed and stained with the fluorescent dye Hoechst 33342 $(0.5 \mu \mathrm{g} / \mathrm{ml})$. The coverslips were mounted on glass slides and examined under a Zeiss Axiovert 200 fluorescence microscope.

\section{Measurement of caspase-3-like activity}

The cells were cultured for 7 days, on poly-D-lysine-coated 24-well cluster plates, at a density of $0.2 \times 10^{6} \mathrm{cells} / \mathrm{cm}^{2}$, before pre-incubation, for $24 \mathrm{~h}$, in the presence or in the absence of BDNF, added to the culture medium. The cells were then incubated with $125 \mu \mathrm{M}$ glutamate in supplemented Neurobasal medium, for $15 \mathrm{~min}$ at $37^{\circ} \mathrm{C}$, in a humidified incubator. In control experiments the cells were incubated in glutamate-free supplemented Neurobasal medium, for the same time period. After stimulation with glutamate, the cells were further incubated with the original culture medium, containing or not BDNF, for $5 \mathrm{~h}$ at $37^{\circ} \mathrm{C}$. The cells were then washed twice with KPM (in mM: $50 \mathrm{KCl}, 50$ PIPES, 10 EGTA and $2 \mathrm{MgCl}_{2}, \mathrm{pH} 7.0$ ), and once with KPM supplemented with CLAP (chymostatin, leupeptin, antipain and pepstatin A, at $1 \mu \mathrm{g} / \mathrm{ml}$ ), phenylmethylsulfonyl fluoride (PMSF) $(100 \mu \mathrm{M})$ and dithiothreitol (DTT) $(1 \mathrm{mM})$. The extracts were prepared in the same medium, supplemented with $0.5 \%$ Triton X-100, and the protein content was determined by the Bio-Rad method. Caspase-3-like activity was measured at $37^{\circ} \mathrm{C}$, in microtiter plates, with a DEVD-pNA concentration of $100 \mu \mathrm{M}$ and a total protein concentration of $150 \mu \mathrm{g} / \mathrm{ml}$. The cleavage of the substrate was measured every $15 \mathrm{~min}$, at $405 \mathrm{~nm}$, using a microtiter plate reader (SLT Spectra, Salzburg, Austria).

\section{Immunoblotting}

The cells were cultured for 7 days, on poly-D-lysine-coated four-well $\left(200 \times 10^{3} \mathrm{cells} / \mathrm{cm}^{2}\right.$, for the time-course experiments) or six-well $\left(90 \times 10^{3} \mathrm{cells} / \mathrm{cm}^{2}\right.$, for the experiments with the inhibitors) cluster plates, before pre-incubation in the presence or in the absence of BDNF. When the effect of inhibitors was tested, the cells were pre-incubated with the compounds for $15 \mathrm{~min}$ before stimulation with the neurotrophin. The cell extracts were prepared as indicated in the previous section, with the exception that KPM was supplemented with $50 \mathrm{mM}$ sodium fluoride and $1.5 \mathrm{mM}$ sodium orthovanadate. The samples were diluted with a $2 \times$ concentrated sample buffer (100 mM Tris, $100 \mathrm{mM}$ glyine, 4\% SDS, $8 \%$ $\beta$-mercaptoethanol, $8 \mathrm{M}$ urea and $1.5 \mathrm{mM}$ sodium orthovanadate), and equal amounts of protein, as determined by the Bio-Rad method, were then separated by electrophoresis on $12 \%$ SDS-polyacrylamide gels (SDS-PAGE) (or 7.5\% gels when pTrk receptors were detected). The proteins were transferred electrophoretically to PVDF membranes, which were then blocked for $1 \mathrm{~h}$ at room temperature, in Tris-buffered saline (137 mM NaCl, $20 \mathrm{mM}$ Tris- $\mathrm{HCl}, \mathrm{pH}$ 7.6) containing $0.1 \%$ Tween 20 (TBST) and $5 \%$ low-fat milk. The membranes were incubated overnight at $4{ }^{\circ} \mathrm{C}$ (or $1 \mathrm{~h}$ at room temperature), with rabbit anti-active MAPK $(1: 3500)$, antiphospho-Akt (Ser473) (1:5000), anti-phospho-Akt (Thr 308) (1:5000), anti-phospho-p38 MAPK $(1: 1000)$ or anti-phospho-JNK $(1: 1000)$ antibodies, or with a mouse anti-ERK (pan) antibody (1:5000), diluted in TBS$\mathrm{T}$ containing $1 \%$ low-fat milk. Incubation with the anti-phospho-TrkA 
(phosphotyrosine 490) $(1: 500)$ antibody was performed in TBS-T with 1\% BSA for the same period of time. After extensive washing with TBS-T, membranes were incubated with the alkaline phosphatase-linked antirabbit or anti-mouse sera, diluted 1:20000 in TBS-T with 1\% low-fat milk, for $1 \mathrm{~h}$ at room temperature. Protein immunoreactive bands were visualized by enhanced chemifluorescence (ECF) on a Storm $860 \mathrm{Gel}$ and Blot Imaging System (Amersham Biosciences), following incubation of the membranes with ECF reagent for $5 \mathrm{~min}$. Where indicated, the membranes were stripped and reprobed with mouse anti- $\alpha$-tubulin $(1: 1000)$ or anti-actin $(1: 1000)$ antibodies.

Immunoblotting experiments for detection of $\mathrm{Bcl}-2$ family members were performed as described above, with slight modifications. The samples were diluted with a $2 \times$ concentrated sample buffer ( $125 \mathrm{mM}$ Tris, pH 6.8, $100 \mathrm{mM}$ glycine, 4\% SDS, $200 \mathrm{mM}$ DTT, 20\% glycerol and 0.01\% bromophenol blue) and the membranes were incubated with rabbit anti-Bcl- $\mathrm{x}_{\mathrm{L}}(1: 1000)$, anti$\operatorname{Bax}(1: 1000)$ or anti-Bad $(1: 1000)$ rabbit antibodies, or with a mouse antiBcl-2 $(1: 500)$ antibody. Where indicated, the membranes were stripped and reprobed with a mouse anti- $\alpha$-tubulin antibody $(1: 1000)$.

\section{Transfection experiments}

Hippocampal neurons were transiently transfected at DIV4 using a calcium phosphate co-precipitation protocol. ${ }^{34}$ Cells at a density of $45 \times 10^{3}$ cells/ $\mathrm{cm}^{2}$ were washed twice with DMEM and then incubated with $250 \mu \mathrm{l}$ of fresh DMEM, for $45 \mathrm{~min}$, in a humidified incubator with $5 \% \mathrm{CO}_{2}$ at $37^{\circ} \mathrm{C}$. During this period of time, the DNA/calcium phosphate precipitate was prepared by mixing one volume of DNA in $250 \mathrm{mM} \mathrm{CaCl}_{2}$ with an equal volume of $2 \times \mathrm{HBS}$ solution $(274 \mathrm{mM} \mathrm{NaCl}, 10 \mathrm{mM} \mathrm{KCl}, 1.4 \mathrm{mM}$ $\mathrm{Na}_{2} \mathrm{HPO}_{4}, 15 \mathrm{mM}$ D-glucose, $42 \mathrm{mM}$ HEPES, pH 7.06). For each well of a 24 multiwell plate, the amount of DNA used was $2 \mu \mathrm{g}$ for MEK KN or Akt $\mathrm{KN}$, and $0.4 \mu \mathrm{g}$ for GFP. In the experiments where GFP toxicity was tested alone, $1 \mu \mathrm{g}$ of GFP DNA was used. The precipitate was let to form for $20 \mathrm{~min}$ at room temperature and then added to cells, which were returned to the incubator for another $20 \mathrm{~min}$. The cells were then washed three times with BME supplemented with $10 \%$ FCS, to stop transfection, and returned to the incubator for another hour. Neurons were then washed twice with plain DMEM and the conditioned medium was added back. Experimental treatments started $24 \mathrm{~h}$ after transfection.

\section{Statistical analysis}

Results are presented as means \pm S.E.M. of the indicated number of experiments, performed in independent preparations. All the results were analyzed using one-way ANOVA, followed by Newman-Keuls multiple comparison test except in Figure 11, where Student's t-test was used.

\section{Acknowledgements}

Ramiro D Almeida was supported by FCT, Portugal. This work was supported by FCT, Portugal (Grants 32631/99 and 46441/2002) and by the Bissaya Barreto Foundation. We are grateful to Dr. Michael Greenberg and Dr. Anne West for comments and technical assistance with the transfection experiments. We also thank Elisabete Carvalho for assistance in the preparations of cell cultures.

\section{References}

1. Huang EJ and Reichardt LF (2003) Trk receptors: roles in neuronal signal transduction. Annu. Rev. Biochem. 72: 609-642
2. Song HJ, Ming GL and Poo MM (1997) CAMP-induced switching in turning direction of nerve growth cones. Nature 388: 275-279

3. Song HJ and Poo MM (1999) Signal transduction underlying growth cone guidance by diffusible factors. Curr. Opin. Neurobiol. 9: 355-363

4. Beck T, Lindholm D, Castren E and Wree A (1994) Brain-derived neurotrophic factor protects against ischemic cell damage in rat hippocampus. J. Cereb. Blood Flow Metab. 14: 689-692

5. Schabitz WR, Schwab S, Spranger M and Hacke W (1997) Intraventricular brain-derived neurotrophic factor reduces infarct size after focal cerebral ischemia in rats. J. Cereb. Blood Flow Metab. 17: 500-506

6. Yamashita K, Wiessner C, Lindholm D, Thoenen H and Hossmann KA (1997) Post-occlusion treatment with BDNF reduces infarct size in a model of permanent occlusion of the middle cerebral artery in rat. Metab. Brain Dis. 12: 271-280

7. Wu D and Pardridge WM (1999) Neuroprotection with noninvasive neurotrophin delivery to the brain. Proc. Natl. Acad. Sci. USA 96: 254-259

8. Schabitz WR, Sommer C, Zoder W, Kiessling M, Schwaninger M and Schwab $S$ (2000) Intravenous brain-derived neurotrophic factor reduces infarct size and counterregulates Bax and Bcl-2 expression after temporary focal cerebral ischemia. Stroke 31: 2212-2217

9. Zhang $Y$ and Pardridge WM (2001) Neuroprotection in transient focal brain ischemia after delayed intravenous administration of brain-derived neurotrophic factor conjugated to a blood-brain barrier drug targeting system. Stroke 32: 1378-1384

10. Kazanis I, Giannakopoulou M, Philippidis H and Stylianopoulou F (2004) Alterations in IGF-I, BDNF and NT-3 levels following experimental brain trauma and the effect of IGF-I administration. Exp. Neurol. 186: 221-234

11. Larsson E, Nanobashvili A, Kokaia Z and Lindvall O (1999) Evidence for neuroprotective effects of endogenous brain-derived neurotrophic factor after global forebrain ischemia in rats. J. Cereb. Blood Flow Metab. 19: 1220-1228

12. Kokaia Z, Nawa H, Uchino H, Elmer E, Kokaia M, Carnahan J, Smith ML, Siesjo BK and Lindvall O (1996) Regional brain-derived neurotrophic factor mRNA and protein levels following transient forebrain ischemia in the rat. Brain Res. Mol. Brain Res. 38: 139-144

13. Poo MM (2001) Neurotrophins as synaptic modulators. Nat. Rev. Neurosci. 2: 24-32

14. Chao MV (2003) Neurotrophins and their receptors: a convergence point for many signalling pathways. Nat. Rev. Neurosci. 4: 299-309

15. Downward J (2004) PI 3-kinase, Akt and cell survival. Semin. Cell Dev. Biol. 15: 177-182

16. Hanada M, Feng $J$ and Hemmings $B A$ (2004) Structure, regulation and function of PKB/AKT - a major therapeutic target. Biochim. Biophys. Acta 1697: 3-16

17. Mattson MP, Lovell MA, Furukawa K and Markesbery WR (1995) Neurotrophic factors attenuate glutamate-induced accumulation of peroxides, elevation of intracellular $\mathrm{Ca}^{2+}$ concentration, and neurotoxicity and increase antioxidant enzyme activities in hippocampal neurons. J. Neurochem. 65: 1740-1751

18. Ankarcrona M, Dypbukt JM, Bonfoco E, Zhivotovsky B, Orrenius S, Lipton SA and Nicotera P (1995) Glutamate-induced neuronal death: a succession of necrosis or apoptosis depending on mitochondrial function. Neuron 15: 961-973

19. Castilho RF, Hansson O, Ward MW, Budd SL and Nicholls DG (1998) Mitochondrial control of acute glutamate excitotoxicity in cultured cerebellar granule cells. J. Neurosci. 18: 10277-10286

20. Kruman II and Mattson MP (1999) Pivotal role of mitochondrial calcium uptake in neural cell apoptosis and necrosis. J. Neurochem. 72: 529-540

21. Nicholls DG (2004) Mitochondrial dysfunction and glutamate excitotoxicity studied in primary neuronal cultures. Curr. Mol. Med. 4: 149-177

22. Kuida K, Zheng TS, Na S, Kuan C, Yang D, Karasuyama H, Rakic $P$ and Flavell RA (1996) Decreased apoptosis in the brain and premature lethality in CPP32deficient mice. Nature 384: 368-372

23. Zou H, Henzel WJ, Liu X, Lutschg A and Wang X (1997) Apaf-1, a human protein homologous to $C$. elegans CED-4, participates in cytochrome cdependent activation of caspase-3. Cell 90: 405-413

24. Gervais FG, Xu D, Robertson GS, Vaillancourt JP, Zhu Y, Huang J, LeBlanc A, Smith D, Rigby M, Shearman MS, Clarke EE, Zheng H, Van Der Ploeg LH, Ruffolo SC, Thornberry NA, Xanthoudakis S, Zamboni RJ, Roy S and Nicholson DW (1999) Involvement of caspases in proteolytic cleavage of Alzheimer's amyloid-beta precursor protein and amyloidogenic $\mathrm{A}$ beta peptide formation. Cell 97: 395-406 
25. Earnshaw WC, Martins LM and Kaufmann SH (1999) Mammalian caspases: structure, activation, substrates, and functions during apoptosis. Annu. Rev. Biochem. 68: 383-424

26. Ip NY, Li Y, Yancopoulos GD and Lindsay RM (1993) Cultured hippocampal neurons show responses to BDNF, NT-3, and NT-4, but not NGF. J. Neurosci. 13: 3394-3405

27. Degterev A, Boyce M and Yuan J (2003) A decade of caspases. Oncogene 22 8543-8567

28. Ekert PG, Silke J and Vaux DL (1999) Caspase inhibitors. Cell Death Differ. 6: 1081-1086

29. Knusel B and Hefti F (1992) K-252 compounds: modulators of neurotrophin signal transduction. J. Neurochem. 59: 1987-1996

30. English JD and Sweatt JD (1996) Activation of p42 mitogen-activated protein kinase in hippocampal long term potentiation. J. Biol. Chem. 271: 24329-24332

31. Alessi DR, Cuenda A, Cohen P, Dudley DT and Saltiel AR (1995) PD 098059 is a specific inhibitor of the activation of mitogen-activated protein kinase kinase in vitro and in vivo. J. Biol. Chem. 270: 27489-27494

32. Favata MF, Horiuchi KY, Manos EJ, Daulerio AJ, Stradley DA, Feeser WS, Van Dyk DE, Pitts WJ, Earl RA, Hobbs F, Copeland RA, Magolda RL, Scherle PA and Trzaskos JM (1998) Identification of a novel inhibitor of mitogen-activated protein kinase kinase. J. Biol. Chem. 273: 18623-18632

33. Davies SP, Reddy H, Caivano M and Cohen P (2000) Specificity and mechanism of action of some commonly used protein kinase inhibitors. Biochem. J. 351: 95-105

34. Bonni A, Brunet A, West AE, Datta SR, Takasu MA and Greenberg ME (1999) Cell survival promoted by the Ras-MAPK signaling pathway by transcriptiondependent and -independent mechanisms. Science 286: 1358-1362

35. Hill MM, Andjelkovic M, Brazil DP, Ferrari S, Fabbro D and Hemmings BA (2001) Insulin-stimulated protein kinase B phosphorylation on Ser-473 is independent of its activity and occurs through a staurosporine-insensitive kinase. J. Biol. Chem. 276: 25643-25646

36. Chen R, Kim O, Yang J, Sato K, Eisenmann KM, McCarthy J, Chen H and Qiu Y (2001) Regulation of Akt/PKB activation by tyrosine phosphorylation. J. Biol. Chem. 276: 31858-31862

37. Powis G, Bonjouklian R, Berggren MM, Gallegos A, Abraham R, Ashendel C, Zalkow L, Matter WF, Dodge J and Grindey G (1994) Wortmannin, a potent and selective inhibitor of phosphatidylinositol-3-kinase. Cancer Res. 54: 2419-2423

38. Vlahos CJ, Matter WF, Hui KY and Brown RF (1994) A specific inhibitor of phosphatidylinositol 3-kinase, 2-(4-morpholinyl)-8-phenyl-4H-1-benzopyran-4one (LY294002). J. Biol. Chem. 269: 5241-5248

39. Datta SR, Dudek H, Tao X, Masters S, Fu H, Gotoh Y and Greenberg ME (1997) Akt phosphorylation of BAD couples survival signals to the cell-intrinsic death machinery. Cell 91: 231-241

40. Sato S, Fujita N and Tsuruo T (2004) Involvement of 3-phosphoinositidedependent protein kinase-1 in the MEK/MAPK signal transduction pathway. J. Biol. Chem. 279: 33759-33767

41. Welsh GI, Foulstone EJ, Young SW, Tavare JM and Proud CG (1994) Wortmannin inhibits the effects of insulin and serum on the activities of glycogen synthase kinase-3 and mitogen-activated protein kinase. Biochem. J. 303 (Part 1): 15-20

42. Cross DA, Alessi DR, Vandenheede JR, McDowell HE, Hundal HS and Cohen P (1994) The inhibition of glycogen synthase kinase-3 by insulin or insulin-like growth factor 1 in the rat skeletal muscle cell line L6 is blocked by wortmannin, but not by rapamycin: evidence that wortmannin blocks activation of the mitogen-activated protein kinase pathway in L6 cells between Ras and Raf. Biochem. J. 303 (Part 1): 21-26

43. Duckworth BC and Cantley LC (1997) Conditional inhibition of the mitogenactivated protein kinase cascade by wortmannin. Dependence on signal strength. J. Biol. Chem. 272: 27665-27670

44. Wennstrom S and Downward J (1999) Role of phosphoinositide 3-kinase in activation of ras and mitogen-activated protein kinase by epidermal growth factor. Mol. Cell. Biol. 19: 4279-4288

45. Chen RW, Qin ZH, Ren M, Kanai H, Chalecka-Franaszek E, Leeds P and Chuang DM (2003) Regulation of C-Jun N-terminal kinase, p38 kinase and AP-1 DNA binding in cultured brain neurons: roles in glutamate excitotoxicity and lithium neuroprotection. J. Neurochem. 84: 566-575

46. Cao J, Semenova MM, Solovyan VT, Han J, Coffey ET and Courtney MJ (2004) Distinct requirements for $p 38 \alpha$ and c-Jun N-terminal kinase stress- activated protein kinases in different forms of apoptotic neuronal death. J. Biol. Chem. 279: 35903-35913

47. Yang DD, Kuan CY, Whitmarsh AJ, Rincon M, Zheng TS, Davis RJ, Rakic P and Flavell RA (1997) Absence of excitotoxicity-induced apoptosis in the hippocampus of mice lacking the Jnk3 gene. Nature 389: 865-870

48. Schwarzschild MA, Cole RL and Hyman SE (1997) Glutamate, but not dopamine, stimulates stress-activated protein kinase and AP-1-mediated transcription in striatal neurons. J. Neurosci. 17: 3455-3466

49. Antonsson B (2004) Mitochondria and the Bcl-2 family proteins in apoptosis signaling pathways. Mol. Cell. Biochem. 256-257: 141-155

50. Ernfors P, Merlio JP and Persson H (1992) Cells expressing mRNA for neurotrophins and their receptors during embryonic rat development. Eur. J. Neurosci. 4: 1140-1158

51. Ringstedt T, Lagercrantz H and Persson H (1993) Expression of members of the trk family in the developing postnatal rat brain. Brain Res. Dev. Brain Res. 72: $119-131$

52. Marsh HN, Scholz WK, Lamballe F, Klein R, Nanduri V, Barbacid M and Palfrey HC (1993) Signal transduction events mediated by the BDNF receptor gp $145^{\text {trkB }}$ in primary hippocampal pyramidal cell culture. J. Neurosci. 13: 42814292

53. Liu CL, Siesjo BK and Hu BR (2004) Pathogenesis of hippocampal neurona death after hypoxia-ischemia changes during brain development. Neuroscience 127: 113-123

54. Nicotera P, Leist M and Manzo L (1999) Neuronal cell death: a demise with different shapes. Trends Pharmacol. Sci. 20: 46-51

55. Koh JY, Gwag BJ, Lobner D and Choi DW (1995) Potentiated necrosis of cultured cortical neurons by neurotrophins. Science 268: 573-575

56. Friedman WJ (2000) Neurotrophins induce death of hippocampal neurons via the p75 receptor. J. Neurosci. 20: 6340-6346

57. Sommerfeld MT, Schweigreiter R, Barde YA and Hoppe E (2000) Downregulation of the neurotrophin receptor TrkB following ligand binding. Evidence for an involvement of the proteasome and differential regulation of TrkA and TrkB. J. Biol. Chem. 275: 8982-8990

58. Wiese S, Digby MR, Gunnersen JM, Gotz R, Pei G, Holtmann B, Lowenthal J and Sendtner M (1999) The anti-apoptotic protein ITA is essential for NGFmediated survival of embryonic chick neurons. Nat. Neurosci. 2: 978-983

59. LaCasse EC, Baird S, Korneluk RG and MacKenzie AE (1998) The inhibitors of apoptosis (IAPS) and their emerging role in cancer. Oncogene 17: 3247-3259

60. Yao R and Cooper GM (1995) Requirement for phosphatidylinositol-3 kinase in the prevention of apoptosis by nerve growth factor. Science 267: 2003-2006

61. Skaper SD, Floreani M, Negro A, Facci L and Giusti P (1998) Neurotrophins rescue cerebellar granule neurons from oxidative stress-mediated apoptotic death: selective involvement of phosphatidylinositol 3-kinase and the mitogenactivated protein kinase pathway. J. Neurochem. 70: 1859-1868

62. Hetman M, Kanning K, Cavanaugh JE and Xia Z (1999) Neuroprotection by brain-derived neurotrophic factor is mediated by extracellular signalregulated kinase and phosphatidylinositol 3-kinase. J. Biol. Chem. 274: 22569-22580

63. Crowder RJ and Freeman RS (1998) Phosphatidylinositol 3-kinase and Akt protein kinase are necessary and sufficient for the survival of nerve growth factor-dependent sympathetic neurons. J. Neurosci. 18: 2933-2943

64. Mazzoni IE, Said FA, Aloyz R, Miller FD and Kaplan D (1999) Ras regulates sympathetic neuron survival by suppressing the p53-mediated cell death pathway. J. Neurosci. 19: 9716-9727

65. Xue L, Murray JH and Tolkovsky AM (2000) The Ras/phosphatidylinositol 3kinase and Ras/ERK pathways function as independent survival modules each of which inhibits a distinct apoptotic signaling pathway in sympathetic neurons. J. Biol. Chem. 275: 8817-8824

66. Klesse LJ and Parada LF (1998) p21 ras and phosphatidylinositol-3 kinase are required for survival of wild-type and NF1 mutant sensory neurons. J. Neurosci. 18: $10420-10428$

67. Dolcet X, Egea J, Soler RM, Martin-Zanca D and Comella JX (1999) Activation of phosphatidylinositol 3-kinase, but not extracellular-regulated kinases, is necessary to mediate brain-derived neurotrophic factor-induced motoneuron survival. J. Neurochem. 73: 521-531

68. Creedon DJ, Johnson EM and Lawrence JC (1996) Mitogen-activated protein kinase-independent pathways mediate the effects of nerve growth factor and cAMP on neuronal survival. J. Biol. Chem. 271: 20713-20718 
69. Gunn-Moore FJ, Williams AG, Toms NJ and Tavare JM (1997) Activation of mitogen-activated protein kinase and p70S6 kinase is not correlated with cerebellar granule cell survival. Biochem. J. 324 (Part 2): 365-369

70. Han BH and Holtzman DM (2000) BDNF protects the neonatal brain from hypoxicischemic injury in vivo via the ERK pathway. J. Neurosci. 20: 5775-5781

71. Mattson MP, Culmsee C and Yu ZF (2000) Apoptotic and antiapoptotic mechanisms in stroke. Cell Tissue Res. 301: 173-187

72. White BC, Sullivan JM, DeGracia DJ, O'Neil BJ, Neumar RW, Grossman LI, Rafols JA and Krause GS (2000) Brain ischemia and reperfusion: molecular mechanisms of neuronal injury. J. Neurol. Sci. 179: 1-33

73. Li F, Omori N, Jin G, Wang SJ, Sato K, Nagano I, Shoji M and Abe K (2003) Cooperative expression of survival $\mathrm{p}$-ERK and $\mathrm{p}$-Akt signals in rat brain neurons after transient MCAO. Brain Res. 962: 21-26

74. Versteeg HH, Evertzen MW, van Deventer SJ and Peppelenbosch MP (2000) The role of phosphatidylinositide-3-kinase in basal mitogen-activated protein kinase activity and cell survival. FEBS Lett. 465: 69-73

75. Conway AM, Rakhit S, Pyne S and Pyne NJ (1999) Platelet-derived-growth-facto stimulation of the p42/p44 mitogen-activated protein kinase pathway in airway smooth muscle: role of pertussis-toxin-sensitive G-proteins, c-Src tyrosine kinases and phosphoinositide 3-kinase. Biochem. J. 337 (Part 2): 171-177

76. Moelling K, Schad K, Bosse M, Zimmermann S and Schweneker M (2002) Regulation of Raf-Akt cross-talk. J. Biol. Chem. 277: 31099-31106

77. Chang SH, Poser S and Xia Z (2004) A novel role for serum response factor in neuronal survival. J. Neurosci. 24: 2277-2285

78. Takei N, Kawamura M, Hara K, Yonezawa K and Nawa H (2001) Brain-derived neurotrophic factor enhances neuronal translation by activating multiple initiation processes: comparison with the effects of insulin. J. Biol. Chem. 276: $42818-42825$

79. Riccio A, Ahn S, Davenport CM, Blendy JA and Ginty DD (1999) Mediation by a CREB family transcription factor of NGF-dependent survival of sympathetic neurons. Science 286: 2358-2361

80. Whitfield J, Neame SJ, Paquet L, Bernard O and Ham J (2001) Dominantnegative c-Jun promotes neuronal survival by reducing BIM expression and inhibiting mitochondrial cytochrome $c$ release. Neuron 29: 629-643

81. Schulte JH, Schramm A, Klein-Hitpass L, Klenk M, Wessels H, Hauffa BP, Eils J, Eils R, Brodeur GM, Schweigerer L, Havers W and Eggert A (2005) Microarray analysis reveals differential gene expression patterns and regulation of single target genes contributing to the opposing phenotype of TrkA- and TrkB-expressing neuroblastomas. Oncogene 24: 165-177

82. Thoenen $H$ and Sendtner M (2002) Neurotrophins: from enthusiastic expectations through sobering experiences to rational therapeutic approaches. Nat. Neurosci. 5 (Suppl): 1046-1050

83. Saragovi HU and Zaccaro MC (2002) Small molecule peptidomimetic ligands of neurotrophin receptors, identifying binding sites, activation sites and regulatory sites. Curr. Pharm. Des. 8: 2201-2216

84. Ambrosio AF, Silva AP, Malva JO, Mesquita JF, Carvalho AP and Carvalho CM (2000) Role of desensitization of AMPA receptors on the neuronal viability and on the $\left[\mathrm{Ca}^{2+}{ }^{2}\right.$; changes in cultured rat hippocampal neurons. Eur. J. Neurosci. 12: 2021-2031

85. Brewer GJ, Torricelli JR, Evege EK and Price PJ (1993) Optimized survival of hippocampal neurons in B27-supplemented Neurobasal, a new serum-free medium combination. J. Neurosci. Res. 35: 567-576 